\title{
Sequential Release of GABA by Exocytosis and Reversed Uptake Leads to Neuronal Swelling in Simulated Ischemia of Hippocampal Slices
}

\author{
Nicola J. Allen, ${ }^{1}$ David J. Rossi, ${ }^{2}$ and David Attwell ${ }^{1}$ \\ ${ }^{1}$ Department of Physiology, University College London, London WC1E 6BT, United Kingdom, and ${ }^{2}$ Neurological Sciences Institute, Oregon Health Sciences \\ University, Beaverton, Oregon 97006
}

\begin{abstract}
GABA release during cerebral energy deprivation (produced by anoxia or ischemia) has been suggested either to be neuroprotective, because GABA will hyperpolarize neurons and reduce release of excitotoxic glutamate, or to be neurotoxic, because activation of $\mathrm{GABA}_{\mathrm{A}}$ receptors facilitates $\mathrm{Cl}^{-}$entry into neurons and consequent cell swelling. We have used the $\mathrm{GABA}_{\mathrm{A}}$ receptors of hippocampal area CA1 pyramidal cells to sense the rise of $[\mathrm{GABA}]_{o}$ occurring in simulated ischemia. Ischemia evoked, after several minutes, a large depolarization to $\sim-20 \mathrm{mV}$. Before this "anoxic depolarization," there was an increase in GABA release by exocytosis (spontaneous IPSCs). After the anoxic depolarization, there was a much larger, sustained release of GABA that was not affected by blocking action potentials, vesicular release, or the glial GABA transporter GAT-3 but was inhibited by blocking the neuronal GABA transporter GAT-1. Blocking $\mathrm{GABA}_{\mathrm{A}}$ receptors resulted in a more positive anoxic depolarization but decreased cell swelling at the time of the anoxic depolarization. The influence of $\mathrm{GABA}_{\mathrm{A}}$ receptors diminished in prolonged ischemia because glutamate release evoked by the anoxic depolarization inhibited $\mathrm{GABA}_{\mathrm{A}}$ receptor function by causing calcium entry through NMDA receptors. These data show that ischemia releases GABA initially by exocytosis and then by reversal of GAT-1 transporters and that the resulting $\mathrm{Cl}^{-}$influx through $\mathrm{GABA}_{\mathrm{A}}$ receptor channels causes potentially neurotoxic cell swelling.
\end{abstract}

Key words: GABA; ischemia; chloride; transporter; GAT-1; excitotoxicity; reversed uptake

\section{Introduction}

Much of the neuronal death caused by cerebral ischemia or anoxia is triggered by glutamate release (Choi and Rothman, 1990; Lipton, 1999), which is initially caused by $\mathrm{Ca}^{2+}$-dependent exocytosis but subsequently by reversal of neuronal glutamate transporters when transmembrane ion gradients run down (Katchman and Hershkowitz, 1993; Madl and Burgesser, 1993; Wahl et al., 1994; Roettger and Lipton, 1996; Rossi et al., 2000). Part of this death occurs as a consequence of glutamate-evoked $\mathrm{Ca}^{2+}$ entry through NMDA receptor channels, which activates $\mathrm{Ca}^{2+}$ dependent enzymes, disrupts mitochondrial function, and triggers necrosis or apoptosis, in part by release of cytochrome $c$ (Ankarcrona et al., 1995; Kluck et al., 1997; Yang et al., 1997; Fujimura et al., 1998). However, chloride removal also reduces early ischemia- and glutamate-evoked cell swelling and death (Rothman, 1985; Olney et al., 1986; Choi, 1987; Goldman and Choi, 1993). This suggests that a component of glutamate- and ischemia-evoked neuronal death is caused by glutamate-

\footnotetext{
Received Dec. 16, 2003; revised March 8, 2004; accepted March 8, 2004.

This work was supported by the Wellcome Trust, a Burroughs-Wellcome Fellowship to D.J.R., a Wolfson-Royal Society Award to D.A., and by the European Union. N.J.A. was in the 4 year PhD Programme in Neuroscience at University College London.

Correspondence should be addressed to Dr. David Attwell, Department of Physiology, University College London, Gower Street, London WC1E 6BT, UK. E-mail: D.Attwell@ucl.ac.uk.

DOI:10.1523/JNEUROSCI.5539-03.2004

Copyright $\odot 2004$ Society for Neuroscience $\quad$ 0270-6474/04/243837-13\$15.00/0
}

depolarizing cells, leading to $\mathrm{Cl}^{-}$influx, followed by water influx and cell swelling, which, if excessive, leads to cell death. Consistent with this, increasing the extracellular osmolarity during transient ischemia reduces neuronal death (Otsubo et al., 1993).

Much interest has focused on the release of glutamate during energy deprivation because of its excitotoxic actions, but GABA release in anoxia/ischemia (Hagberg et al., 1985) is also likely to be important, for two reasons. First, the activation of $\mathrm{GABA}_{\mathrm{A}}$ receptors will affect the depolarization of neurons that occurs and thus alter the extracellular glutamate concentration that is produced by reversal of glutamate transporters (the glutamate concentration increases exponentially with membrane depolarization) (Attwell et al., 1993). In adult neurons, the chloride reversal potential is more negative than the resting potential, and $\mathrm{GABA}_{\mathrm{A}}$ receptor activation is expected to reduce the depolarization occurring, so GABA release might be neuroprotective. Second, consideration of cell death induced by swelling suggests a potentially toxic action of ischemic GABA release. Activation of $\mathrm{GABA}_{\mathrm{A}}$ receptors will increase $\mathrm{Cl}^{-}$entry when glutamate depolarizes neurons (Hansen, 1985; Inglefield and Schwartz-Bloom, 1998) and thus increase water entry and cell swelling. Consistent with this, in retinal and cerebellar cells, cell death evoked by activation of glutamate receptors can be reduced by blocking $\mathrm{GABA}_{\mathrm{A}}$ receptors (Chen et al., 1999).

Despite the potential importance of GABA release during CNS energy deprivation and therapeutic developments based on 
modulating the actions of GABA (Green et al., 2000), there is no consensus on its release mechanism. GABA release has been attributed to exocytosis dependent on extracellular $\mathrm{Ca}^{2+}$ (Djali and Dawson, 2001), to leak through ruptured cell membranes (Phillis et al., 1994), or to reversal of $\mathrm{Na}^{+}$-dependent GABA transporters (Zeevalk and Nicklas, 1996; Saransaari and Oja, 1997). We have, therefore, reinvestigated the mode of release of GABA and its effects when the hippocampus is exposed to simulated ischemia. The results show that GABA is released initially by exocytosis and then by reversed uptake and that GABA release reduces the depolarization produced by ischemia but increases cell swelling in early ischemia.

\section{Materials and Methods}

Brain slices and extracellular solution. Sprague Dawley rats, $12 \mathrm{~d}$ old, were killed by cervical dislocation in accordance with United Kingdom animal experimentation regulations. Thin $(225 \mu \mathrm{m})$ hippocampal slices were cut using a vibrating slicer, and patch-clamp recordings from visually identified pyramidal cells in area CA1 were performed (Rossi et al., 2000). Experiments were at $33 \pm 1^{\circ} \mathrm{C}$, with the slices submerged in flowing $(10 \mathrm{ml} / \mathrm{min}$ ) extracellular solution containing (in $\mathrm{mM}) 126 \mathrm{NaCl}, 24$ $\mathrm{NaHCO}_{3}, 1 \mathrm{NaH}_{2} \mathrm{PO}_{4}, 2.5 \mathrm{KCl}, 2.5 \mathrm{CaCl}_{2}, 2 \mathrm{MgCl}_{2}$, and 10 D-glucose (gassed with $95 \% \mathrm{O}_{2} / 5 \% \mathrm{CO}_{2}$ ), pH 7.4. Kynurenic acid (1 mm; Sigma, Paisley, UK) was included in the dissection and incubation solution (to block glutamate receptors, to reduce potential excitotoxic damage) but was omitted from the superfusion solution. Ischemia was simulated by replacing $10 \mathrm{~mm}$ glucose with $7 \mathrm{~mm}$ sucrose, bubbling with $95 \% \mathrm{~N}_{2} / 5 \%$ $\mathrm{CO}_{2}$ and, to get a reproducible fast onset to the ischemic response, adding $2 \mathrm{~mm}$ Na-iodoacetate (Sigma) and $1 \mathrm{~mm} \mathrm{Na-cyanide} \mathrm{(BDH,} \mathrm{Poole,} \mathrm{UK)}$ to block glycolysis and oxidative phosphorylation (Reiner et al., 1990). Drugs were added directly to the external solution from stock solutions in water [GABAzine, SKF-89976A, NBQX, D-AP5, and MK-801 were obtained from Tocris (Bristol, UK), TTX was from Alomone (Jerusalem, Israel), and 7-chlorokynurenate was from Sigma]. For experiments using concanamycin to block vesicle loading with transmitter, slices were presoaked for at least $2 \mathrm{hr}$ in $0.5 \mu \mathrm{M}$ concanamycin (ICN Biomedicine, Aurora, $\mathrm{OH}$ ), whereas control slices were soaked in external solution lacking concanamycin (both solutions contained $1 \mathrm{~mm}$ kynurenic acid to block glutamate receptors; concanamycin was made up as a $50 \mu \mathrm{M}$ stock in DMSO, and a corresponding amount of DMSO was added to the control soaking solution). Concanamycin was not present in the subsequent recording solution. For $\beta$-alanine pretreatment, slices were soaked in solution containing $1 \mathrm{~mm} \beta$-alanine (Sigma) for $1 \mathrm{hr}$ before recording in solution lacking $\beta$-alanine.

Whole-cell clamping. Patch pipettes were pulled from thick-walled borosilicate glass capillaries and filled, for whole-cell voltage-clamp recordings with $\mathrm{E}_{\mathrm{Cl}}=0 \mathrm{mV}$, with an internal solution containing (mM) 130 $\mathrm{CsCl}\left(\mathrm{Cs}^{+}\right.$was used as the main cation rather than $\mathrm{K}^{+}$to improve voltage uniformity), $4 \mathrm{NaCl}, 10$ HEPES, 10 BAPTA, 4 MgATP, 0.5 $\mathrm{Na}_{2} \mathrm{GTP}$, and 10 QX-314 (to suppress voltage-gated sodium currents), $\mathrm{pH}$ adjusted to 7.2 with $\mathrm{CsOH}$. In some experiments, BAPTA was replaced with $5 \mathrm{~mm}$ EGTA and $0.5 \mathrm{~mm} \mathrm{CaCl}_{2}$, as described in Results. All experiments were performed at a holding potential of $-33 \mathrm{mV}$. Electrode junction potentials were compensated for. To stimulate synaptic inputs, glass pipettes (resistance, $\sim 1-2 \mathrm{M} \Omega$ filled with extracellular medium) were placed in the stratum radiatum or stratum oriens.

Series resistance. The series resistance in the whole-cell mode was typically $4 \mathrm{M} \Omega$ before compensation and $1-2 \mathrm{M} \Omega$ after $60 \%$ compensation. The large size of the current changes evoked by ischemia [up to $6 \mathrm{nA}$ at the peak of the anoxic depolarization (AD)] means that, even after compensation, significant series resistance voltage errors will inevitably occur (a detailed analysis was described by Hamann et al., 2002). Data are presented here without correction for this, because the series resistance was similar in different experimental conditions, and correcting for series resistance voltage errors would not alter the conclusions reached.

Perforated patch recording. To record the voltage or current response of pyramidal cells to ischemia without perturbing intracellular calcium buffering or the intracellular chloride concentration, and hence $\mathrm{GABA}_{\mathrm{A}}$ receptor-mediated currents, we used perforated patch recording. The electrode solution normally contained (in mM) $135 \mathrm{KCl}, 10 \mathrm{HEPES}, 2$ $\mathrm{MgCl}_{2}, 5 \mathrm{Na}_{2}$ EGTA, $0.5 \mathrm{CaCl}_{2}$, and $2 \mathrm{MgATP}, \mathrm{pH}$ adjusted to 7.2 with $\mathrm{KOH}$, to which gramicidin A ( $64 \mu \mathrm{g} / \mathrm{ml}$; Sigma) was added on the day of use (the tip of the electrode was filled with solution lacking gramicidin to facilitate seal formation). Gramicidin A allows monovalent cations to cross the membrane, but not anions or divalent cations (Akaike, 1996). In some experiments (see Fig. $9 C, D$ ), as noted in Results, $\mathrm{Na}_{2}$ EGTA and $\mathrm{CaCl}_{2}$ were replaced with $10 \mathrm{~mm}$ BAPTA. The electrode solution also contained Lucifer yellow $(0.8 \mathrm{mg} / \mathrm{ml})$ to allow visualization of whether the perforated patch had altered to the whole-cell mode, allowing Lucifer into the cell. Typically, after sealing onto the cell membrane, it took $\sim 30-40$ min for sufficient perforant to enter the membrane to lower the series resistance below $25 \mathrm{M} \Omega$. The series resistance was then compensated to $\sim 15 \mathrm{M} \Omega$. Maintaining perforated patch recordings was not difficult in normal solution, but the cell swelling produced by metabolic inhibition often led to the perforated patch rupturing after the $\mathrm{AD}$ (ascertained by a sudden change of membrane current and the entry of Lucifer yellow into the cell). Electrode junction potentials were compensated for.

Field potential recording. Noninvasive recording of the time of the AD was performed by recording the field potential with an extracellular recording electrode (a patch pipette filled with external solution) placed in the pyramidal cell proximal apical dendrite layer (Rader and Lanthorn, 1989).

Detection of cell swelling. To analyze the effect of blocking GABA receptors on the swelling that occurred at the time of the $\mathrm{AD}$, we used the fact that in submerged slices swelling leads to less scattering of light passing through the slice and so increases the intensity of transmitted light (Kreisman et al., 1995; Joshi and Andrew, 2001). This is because intracellular organelles scatter light and reduce the transmitted light, but when cells swell, the organelles are diluted, reducing scattering and increasing transmittance. We used the microscope white light illuminator (set to very dim illumination) as the light source and detected the light transmitted through an area of size $120 \times 96 \mu \mathrm{m}$ centered on the pyramidal cell somata in CA1, using a photomultiplier connected to a current to voltage converter. Signals were filtered at $1 \mathrm{~Hz}$. As a check on the high time resolution data obtained in this way, we also measured the soma diameter of CA1 pyramidal cells. A $12.5 \%$ increase in light transmittance measured $5 \mathrm{~min}$ after the peak of the $\mathrm{AD}$ (see Fig. $7 E$ ) was correlated with a $43 \%$ increase of soma diameter, from $10.66 \pm 0.17 \mu \mathrm{m}$ before ischemia to $15.22 \pm 0.56 \mu \mathrm{m} 5 \mathrm{~min}$ after the $\mathrm{AD}\left(p=1.7 \times 10^{-8} ; 111\right.$ cells before ischemia; 25 cells after the AD).

Data analysis. Data are presented as the means \pm SEM, and the significance of changes was assessed with a two-tailed Student's $t$ test. Most figures showing slow responses to ischemia are filtered at $5 \mathrm{~Hz}$ for clarity of display, so spontaneous IPSCs are not visible. For analysis and display of spontaneous IPSCs, data were filtered at $2-5 \mathrm{kHz}$. When quantifying IPSC occurrence, IPSCs were defined as current deflections that had an amplitude (measured from the mean current) greater than the peak-to-peak amplitude of the current noise and with a decay time constant at least twofold slower than the rise time (on average, it was fourfold slower). Events $<10 \mathrm{pA}$ in amplitude were not detectable above the baseline noise.

\section{Results}

\section{Action potential-independent exocytotic release of GABA} occurs before the $\mathrm{AD}$

To analyze the mechanisms of GABA release in ischemia, we whole-cell clamped area CA1 pyramidal cell layer neurons and used their $\mathrm{GABA}_{\mathrm{A}}$ receptors as sensors of the rise of extracellular GABA concentration occurring in ischemia. The excitatory pyramidal cells constitute $98 \%$ of the cell bodies in the pyramidal cell layer (Aika et al., 1994) and are thought neither to release GABA exocytotically nor to express GABA transporters (Ribak et al., 1996; Yan et al., 1997), so using a pyramidal cell as a sensor should not alter the ischemia-evoked $[\mathrm{GABA}]_{\mathrm{o}}$ change. The chloride concentration in the pipette was set equal to that in the external solution, to minimize changes of $\mathrm{E}_{\mathrm{Cl}}$ caused by ischemia (Ingle- 
A

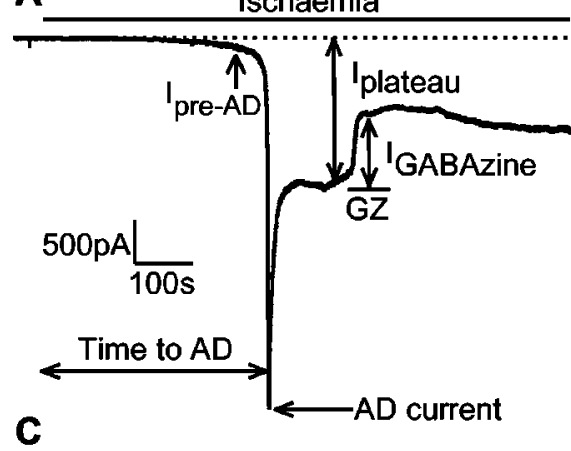

B
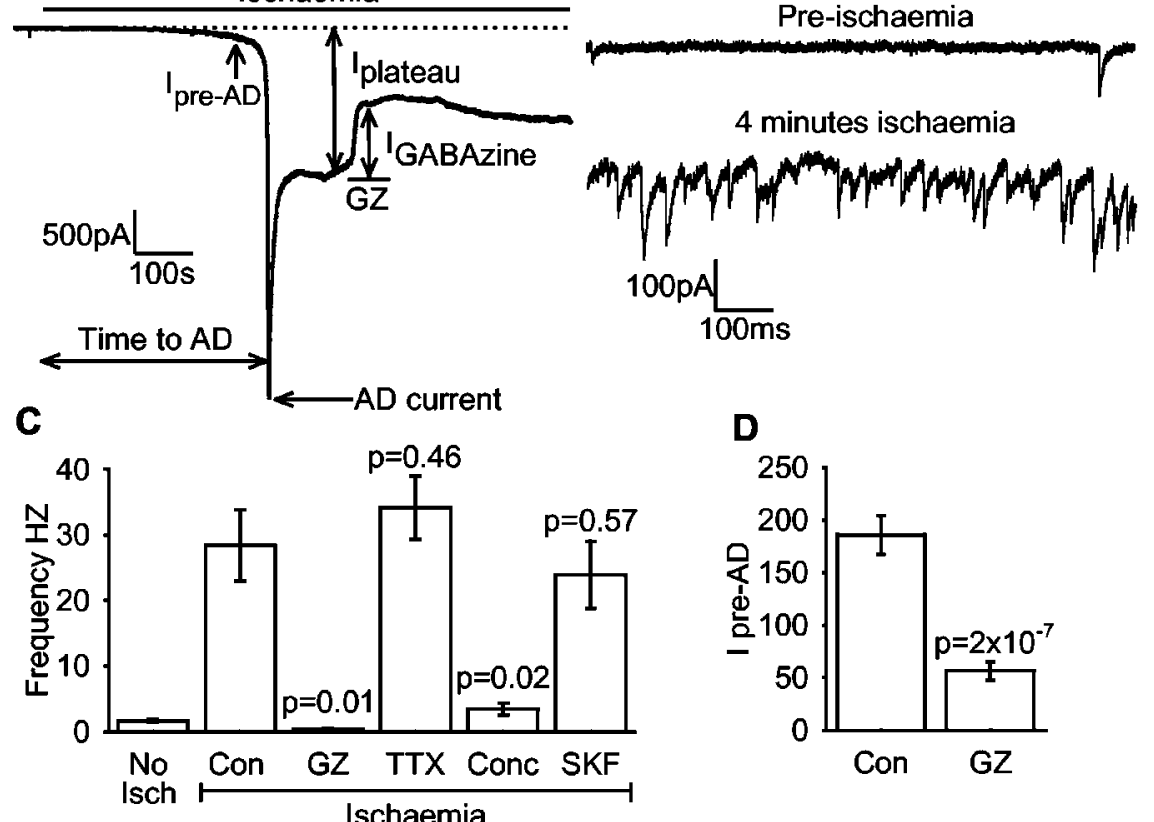

D

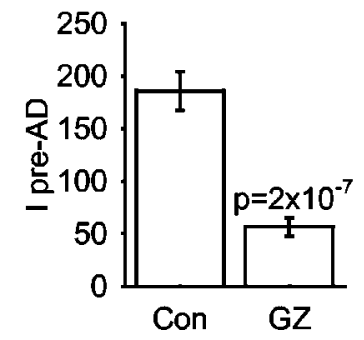

E

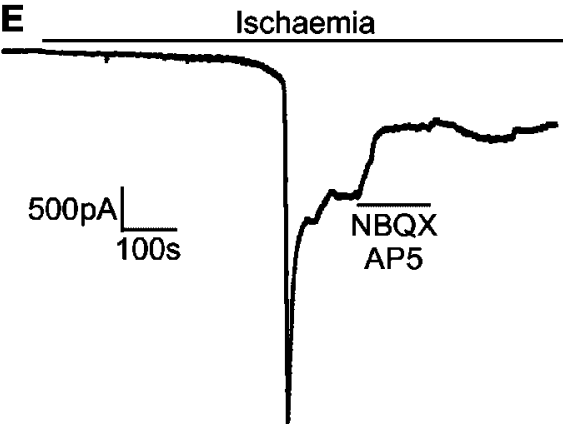

$\mathbf{F}$

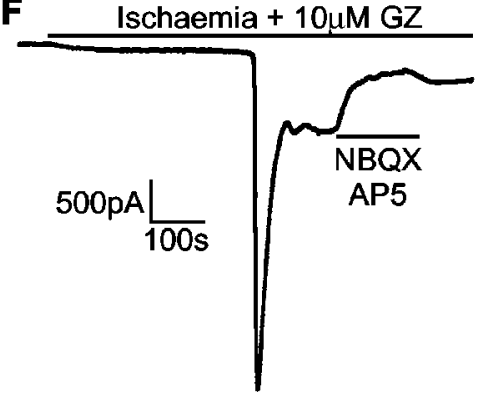

G

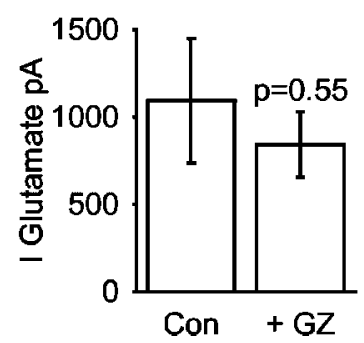

H

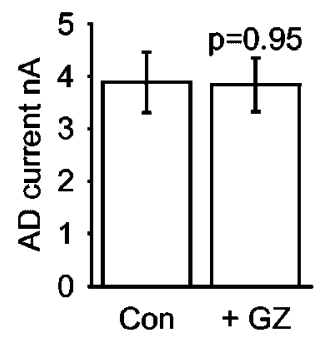

1

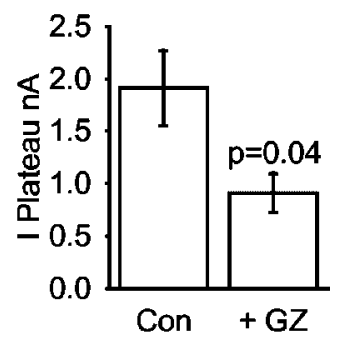

Figure 1. Ischemia evokes GABA release before and after the AD. A, Current response of a CA1 pyramidal cell to ischemia in the whole-cell voltage clamp mode, with measured parameters marked (dashed line indicates the extrapolated baseline). The plateau current was measured 2 min after the $A D$; GABAzine (GZ) was then applied to assess $G A B A$ release, and the current suppressed was measured 3 min after the $A D$. $B$, Expanded regions taken from $1 \mathrm{~min}$ before and $4 \mathrm{~min}$ after ischemia solution was applied ( $2 \mathrm{~min}$ before the $A D$ ), showing that there is an increase in the frequency of spontaneous postsynaptic currents in the buildup to the AD. C, Frequency of spontaneous postsynaptic currents in non-ischemic solution (No Isch; 27 cells) and 4 min after application of normal ischemic solution, or ischemic solution containing $10 \mu \mathrm{m}$ GABAzine (GZ), $1 \mu \mathrm{m}$ TTX, or $100 \mu \mathrm{M}$ SKF-89976A (SKF), or normal ischemic solution in slices pretreated with concanamycin (Conc) (4 cells for each ischemic condition). D, Magnitude of the pre-AD current (1 min before the AD, measured from the pre-ischemic baseline) in control ischemia solution and in ischemia solution containing $10 \mu \mathrm{mGABAzine.E,Application} \mathrm{of} 25 \mu \mathrm{m} \mathrm{NBQX}$ and $50 \mu \mathrm{m} A \mathrm{P} 5$ shows that about half of the plateau current after the AD is generated by glutamate receptors. $F$, For ischemia in the presence of GABAzine throughout, NBQX plus AP5 blocks almost all of the plateau current. G, The size of the glutamate receptor-mediated current (measured as in $A$ for the GABAzine-blocked current) was not affected by blocking $G_{A B A_{A}}$ receptors (6 interleaved cells in each group). $H_{\text {, }}$ The amplitude of the $A D$ current was not affected by blocking $G_{A B A_{A}}$ receptors. I, The plateau current was halved in the presence of GABAzine. All data are at $-33 \mathrm{mV}$.

field and Schwartz-Bloom, 1998); thus, $\mathrm{E}_{\mathrm{Cl}}=0 \mathrm{mV}$ and $\mathrm{GABA}_{\mathrm{A}}$ receptor-mediated currents are inward.

Figure $1 \mathrm{~A}$ shows the response to ischemia of a whole-cell clamped pyramidal neuron. On applying ischemic solution, a slowly developing inward current is seen for the first $\sim 6 \mathrm{~min}$, after which a sudden large inward current occurs that then sags back to a smaller inward plateau. The large inward current is the cause of the $\mathrm{AD}$ (Hansen, 1985), which occurs in cells that are not voltage clamped (see Fig. 6), and will be termed the $\mathrm{AD}$ current. It coincides with an increase in $\left[\mathrm{K}^{+}\right]_{\mathrm{o}}$ to $\sim 50-60 \mathrm{~mm}$ caused by the sodium pump being inhibited by [ATP] falling (Hansen, 1985) and a release of glutamate that activates NMDA and AMPA receptors (Fig. $1 E$ ) (for a detailed characterization, see Rossi et al., 2000). The time at which the AD occurred was not significantly different when measured noninvasively with field potential recording (see Materials and Methods; $386 \pm 6 \mathrm{sec}$ after the start of ischemia in seven slices; data not shown) or with patch clamping as in Figure $1(398 \pm 10 \mathrm{sec}$ in 10 cells; $p=0.37$ compared with field potential recording), showing that patch clamping of the sensing cell does not grossly alter the events generating the $\mathrm{AD}$.

The enlarged traces in Figure $1 B, 1 \mathrm{~min}$ before ischemia and $4 \mathrm{~min}$ after ischemia, show that the inward current developing before the $\mathrm{AD}$ includes numerous spontaneous synaptic currents (Fleidervish et al., 2001). These occurred at a rate $(28.4 \pm 5.4$ $\mathrm{Hz}$ in four cells, averaged from 3.5-4 min after the start of ischemia) that was 20 -fold higher than in non-ischemic solution $\left(1.4 \pm 0.2 \mathrm{~Hz}\right.$ in 27 cells; $\left.p=2 \times 10^{-14}\right)$ (Fig. 1C). They were reduced in frequency by $98.7 \%$ by $10 \mu \mathrm{M}$ GABAzine (SR95531; to $0.36 \pm 0.12 \mathrm{~Hz}$ in four cells; $p=0.01$ ) (Fig. 1C), consistent with previous studies on non-ischemic CA1 pyramidal cells that found that sIPSCs comprise up to $97 \%$ of recorded spontaneous currents (Ropert et al., 1990; De Simoni et al., 2003), with sEPSCs being far less numerous. They were not significantly affected by TTX ( $1 \mu \mathrm{M}$; four cells) (Fig. 1C). Thus, essentially all of the spontaneous events seen before the $\mathrm{AD}$ in Figure $1 B$ are miniature IPSCs produced by exocytosis of GABA-containing vesicles.

Consistent with GABA release occurring before the $\mathrm{AD}$, the presence of $10 \mu \mathrm{M}$ GABAzine (as in Fig. $1 F$ ) reduced the mean inward current 1 min before the $\mathrm{AD}$ (measured from the pre-ischemia baseline and labeled pre-AD current in Fig. $1 A$ ) from $186 \pm 18 \mathrm{pA}$ (in 33 control ischemia cells) to $56 \pm 9 \mathrm{pA}$ (in 5 cells in ischemia with GABAzine; $p=2 \times 10^{-7}$ ) (Fig. $1 D$ ). Thus, GABA release generates a mean current of $\sim 130 \mathrm{pA} 1 \mathrm{~min}$ before the AD.

\section{GABA is released after the $A D$}

Applying GABAzine 2 min after the peak of the $\mathrm{AD}$ current in Figure $1 \mathrm{~A}$ suppressed approximately half of the inward plateau 
current at that time, showing that GABA is being released after the $\mathrm{AD}$ as well as before it. The GABAzine-suppressed current $(609 \pm 35 \mathrm{pA}$ in 63 cells) was larger than the GABA-mediated current that developed during the spontaneous synaptic currents seen before the $\mathrm{AD}(\sim 130 \mathrm{pA} 1 \mathrm{~min}$ before the $\mathrm{AD}$; see above), demonstrating that after the $\mathrm{AD}$ more GABA is being released.

The $\mathrm{GABA}_{\mathrm{A}}$ receptor blocker bicuculline $(40 \mu \mathrm{M})$ suppressed a current after the $\mathrm{AD}(516 \pm 96 \mathrm{pA})$ that was not significantly different from that suppressed by GABAzine $(603 \pm 135 \mathrm{pA} ; p=$ 0.62 ; five interleaved slices studied for each blocker). This implies that there is no significant contribution to the ischemia-evoked GABA-activated conductance from the bicuculline-sensitive, GABAzine-insensitive $\mathrm{GABA}_{\mathrm{A}}$ receptors that generate a small tonic conductance in pyramidal cells (Bai et al., 2001); we found that bicuculline suppressed a tonic inward current of $16.3 \pm 1.3$ $\mathrm{pA}$ in four cells in non-ischemic solution. This may be because these receptors are high affinity and are saturated even in nonischemic conditions (Yeung et al., 2003). For quantifying ischemia-evoked GABA release, we preferred to use GABAzine rather than bicuculline as a $\mathrm{GABA}_{\mathrm{A}}$ receptor blocker because bicuculline also blocks some potassium channels (Khawaled et al., 1999).

Applying glutamate receptor blockers after the $\mathrm{AD}$ also blocked about half of the plateau current (Fig. 1E), suggesting that most of the rest of the (non-GABA-mediated) post-AD plateau current is produced by activation of glutamate receptors, as reported previously (Rossi et al., 2000). The size of the glutamatemediated current during the post-AD plateau was not significantly affected by blocking $\mathrm{GABA}_{\mathrm{A}}$ receptors (Fig. $1 F, G$ ). The amplitude of the $\mathrm{AD}$ current was not significantly different in the presence of GABAzine (Fig. $1 E, F, H$ ), but the amplitude of the plateau current 2 min after the peak of the AD was halved ( $p=$ 0.04 ) by $10 \mu \mathrm{M}$ GABAzine (Fig. $1 E, F, I$ ), confirming that the plateau current is mediated by a combination of glutamate and GABA receptor activation.

$\mathrm{GABA}$ release after the $\mathrm{AD}$ is not by exocytosis

To investigate the mechanism of GABA release after the $A D$, we used the size of the current suppressed when GABAzine was applied 2 min after the AD (as in Fig. $1 A$ ) as a measure of GABA release. The concentration of GABAzine used $(10 \mu \mathrm{M})$ was sufficient to block $94 \pm 4 \%$ of the plateau current produced by the application of $100 \mu \mathrm{M}$ GABA to CA1 pyramidal cells in nonischemic solution (the mean GABA-evoked current without GABAzine was $2733 \pm 745 \mathrm{pA}$ peak; $1597 \pm 339 \mathrm{pA}$ plateau; three cells; data not shown), i.e., sufficient to almost completely block $\mathrm{GABA}_{\mathrm{A}}$-mediated currents of the size likely to be present during the post-AD plateau (the plateau current is $\sim 2 \mathrm{nA}$, approximately half of which is blocked by glutamate receptor blockers) (Fig. 1I). Control experiments, superfusing $1 \mathrm{~mm}$ GABA 2 min after the $\mathrm{AD}$, established that the $\mathrm{GABA}_{\mathrm{A}}$ receptors were not saturated at this time (see Fig. $8 D$ ), and so the GABAzinesuppressed current is expected to become smaller if GABA release is decreased.

Applying TTX $(1 \mu \mathrm{M})$, to prevent action potentials, had no effect on the GABA-mediated current after the $\mathrm{AD}$ (Fig. 2A,B), establishing that action potentials do not contribute significantly to the GABA present after the AD (just like before the AD) (Fig. $1 C)$. TTX also had no significant effect on the time to the AD or the amplitude of the AD current (data not shown).

To block exocytotic release of vesicular GABA, we soaked slices in the vesicular $\mathrm{H}^{+}$-ATPase inhibitor concanamycin $(0.5$ $\mu \mathrm{M})$ before recording. By abolishing the proton electrochemical
A Ischaemia

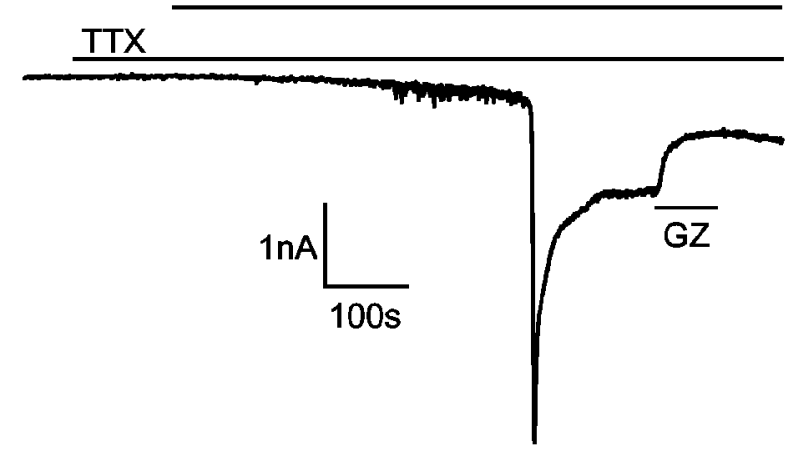

B
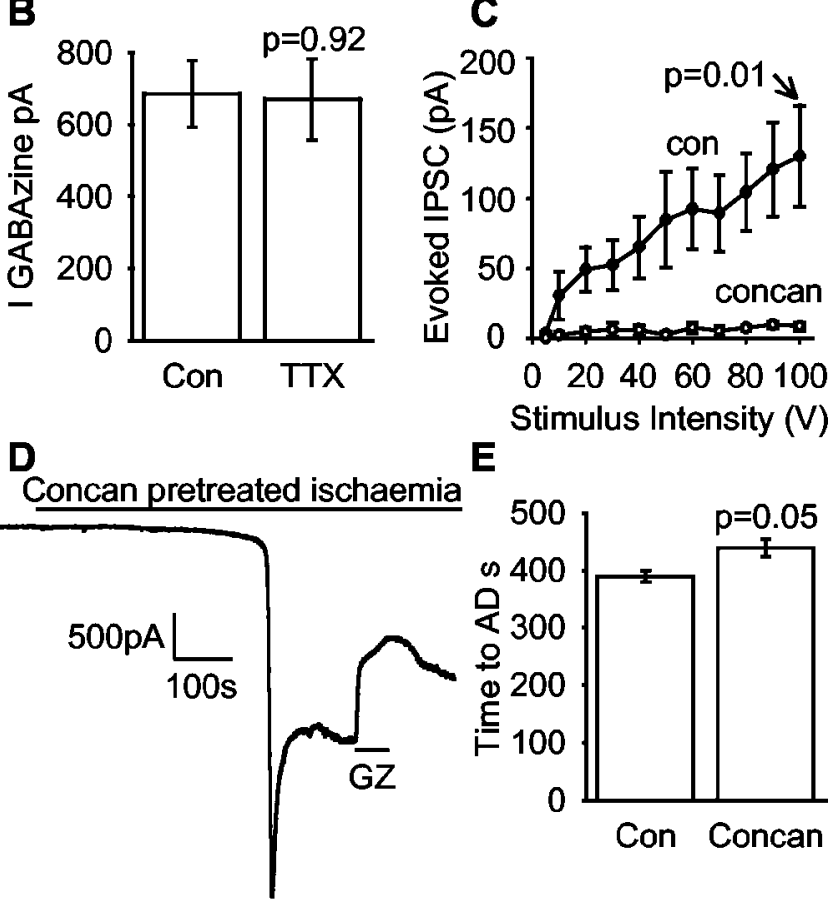

E

Stimulus Intensity (V)

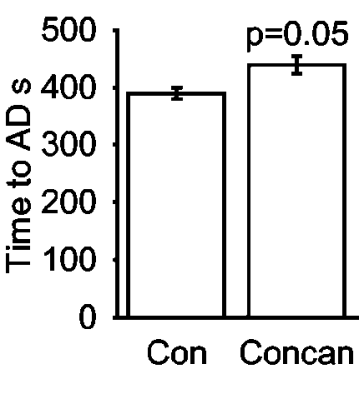

$\mathbf{F}$

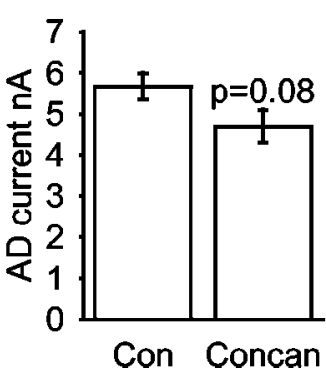

G

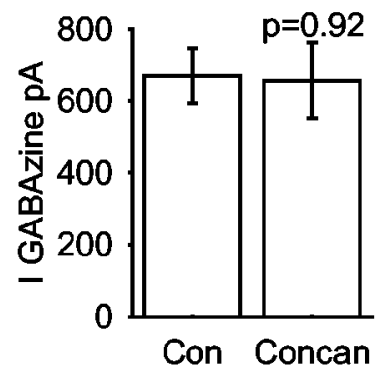

Figure 2. GABA release after the $A D$ is not action potential evoked and is not by exocytosis. $A$, In the presence of $1 \mu \mathrm{M}$ TTX to block action potentials during application of ischemia solution, the current response of $C A 1$ pyramidal neurons to ischemia was unchanged (compare Fig. 1A). $B$, The size of the post-AD GABAzine-blocked current was not significantly different in the presence and absence of TTX ( 9 control cells, 6 interleaved TTX cells). C, Depleting vesicles of GABA using concanamycin abolished IPSCs evoked in CA1 pyramidal neurons by electrical stimulation (in the presence of $25 \mu \mathrm{m} \mathrm{NBQX}$ and $50 \mu \mathrm{m}$ AP5 to block glutamate receptors), showing that vesicle depletion had been successful [ 7 control (Con) cells, 7 concanamycin (Concan) cells; $p<0.05$ for all stimulation voltages above $10 \mathrm{~V}$ ]. D, Blocking vesicular GABA release had little effect on the response of CA1 pyramidal neurons to ischemia (compare Fig. 1A). E, Blocking vesicular $G A B A$ release slightly prolonged the time to the $A D$. F, Blocking vesicular $G A B A$ release had no significant effect on the size of the $A D$ current. $G$, The amplitude of the GABAzineblockable current after the $A D$ was not affected by blocking vesicular release (10 cells in control ischemia solution, 8 interleaved cells pretreated with concanamycin for $E-G)$. All data are at $-33 \mathrm{mV}$. 


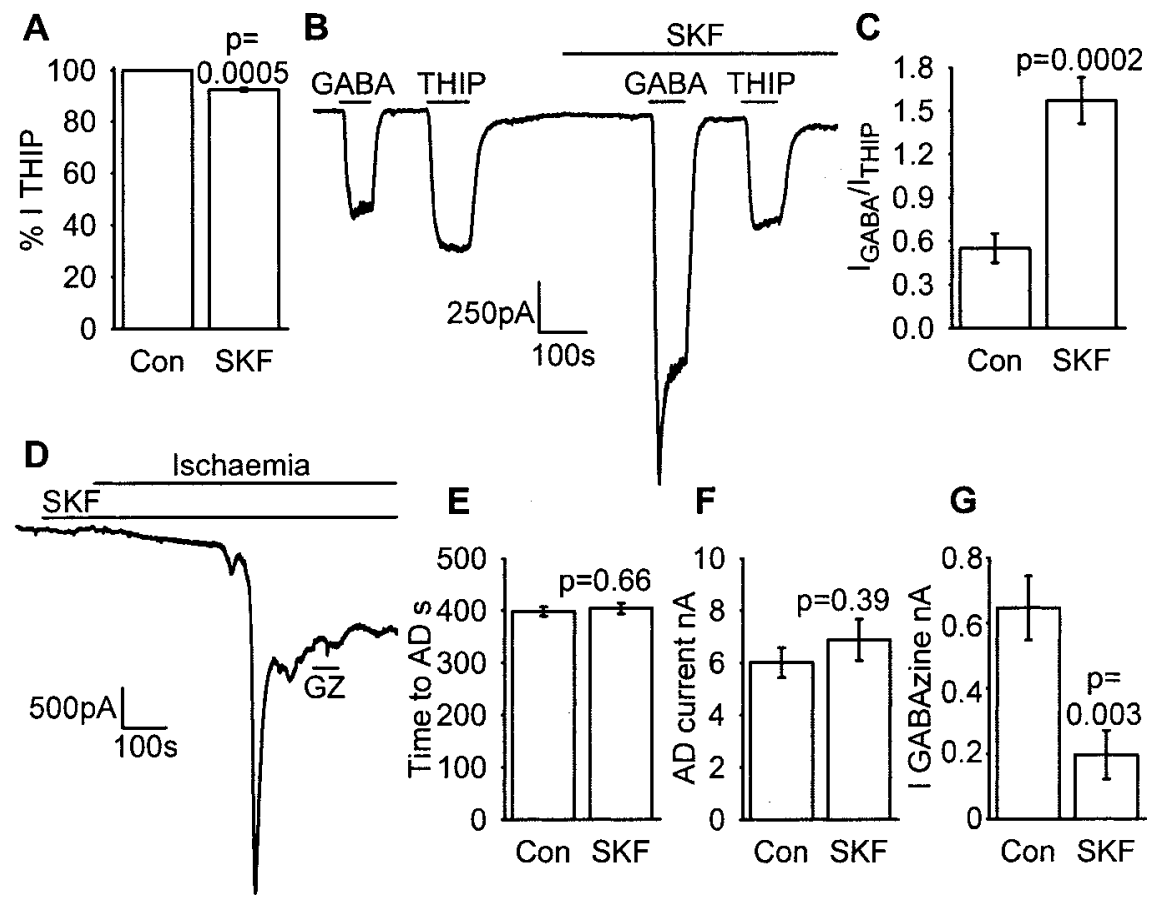

Figure 3. GABA release after the $\mathrm{AD}$ is mostly by reversed operation of the GAT-1 transporter. $A, \mathrm{SKF}-89976 \mathrm{~A}(100 \mu \mathrm{M})$ only slightly reduced the response to the nontransported GABA analog THIP (20 $\mu \mathrm{M}$, in non-ischemic solution). Mean data from five cells for the size of the THIP response in SKF-89976A normalized to its response in the absence of $100 \mu \mathrm{m}$ SKF-89976A (602 \pm 24 $\mathrm{pA}) . B$, The ratio of the responses of a pyramidal cell to GABA (10 $\mu \mathrm{M})$ and to THIP (in non-ischemic solution) was increased by 100 $\mu$ M SKF-89976A. C, Mean ratio of currents as in B (8 cells). D-G, SKF-89976A reduces ischemia-evoked GABA release after the AD. $D$, In the presence of SKF-89976A throughout ischemia to block GAT-1, the GABAzine-evoked current after the AD was reduced, showing a reduction of GABA release. $E$, The time of the AD was not altered when GAT-1 was blocked with SKF-89976A. F, The amplitude of the AD current was not affected by SKF-89976A. G, The GABAzine-blockable current was reduced by $70 \%$ when GAT-1 was blocked (7 cells studied in control ischemia solution, 8 interleaved cells with SKF-89976A). All data are at $-33 \mathrm{mV}$.

9gradient across the vesicle membrane (Manabe et al., 1993; Dröse and Altendorf, 1997), this drug prevents the accumulation of transmitter within vesicles and thereby prevents transmitter release by exocytosis (Zhou et al., 2000; Rossi et al., 2003). We first checked that concanamycin did indeed block exocytotic release of GABA by recording evoked IPSCs in normal solution containing glutamate receptor blockers. Soaking in concanamycin reduced the amplitude of IPSCs evoked in CA1 pyramidal neurons by stimulating GABAergic interneurons in the stratum radiatum or stratum oriens (on the border of CA1/CA3) by $\sim 90 \%$ at all stimulation intensities (Fig. 2C), compared with data recorded from interleaved slices soaked in solution lacking concanamycin. Similarly, when ischemic solution was applied to slices that had been soaked in concanamycin, the rate of occurrence of spontaneous synaptic currents (averaged over the period from 3.5-4 min after the start of ischemia) was reduced by $88 \%$ (Fig. 1C), from $28.4 \pm 5.4 \mathrm{~Hz}$ without concanamycin pretreatment to $3.4 \pm 0.9 \mathrm{~Hz}$ with concanamycin pretreatment $(p=$ 0.02 ; four cells each). However, the AD occurred with approximately its normal latency (Fig. 2E) and current amplitude (Fig. $2 F)$, and the size of the GABAzine-suppressed current after the AD was unaffected (Fig. 2G).

Thus, most of the GABA release after the $\mathrm{AD}$ is not by exocytosis.

\section{GABA release after the AD is primarily by reversal of GAT-1 GABA transporters}

Most of the glutamate released by simulated ischemia is released by reversal of glutamate transporters (Rossi et al., 2000). To test whether GABA transporters also reverse, we used SKF-89976A, a nontransported inhibitor of the GABA transporter GAT-1 (Borden et al., 1994), which is present mainly in interneurons but also in astrocytes in the hippocampus (Ribak et al., 1996; Yan et al., 1997).

To check that SKF-89976A did block these transporters, in slices in nonischemic solution we recorded the response of pyramidal cells to superfused GABA $(10 \mu \mathrm{M})$ and THIP (4,5,6,7-tetrahydroisoxazolo[5,4-c]pyridin-3-ol; $20 \mu \mathrm{M})$, an agonist of the $\mathrm{GABA}_{\mathrm{A}}$ receptor that is not transported by GABA transporters (Kemp et al., 1986; Korn and Dingledine, 1986). SKF-89976A (100 $\mu \mathrm{M})$ itself did not produce a significant current $(3.0 \pm 1.8 \mathrm{pA}$ inward current at $-33 \mathrm{mV} ; p=0.18)$, and when applied on the plateau of the response to THIP $(\sim 0.6 \mathrm{nA})$ it reduced the response to THIP by only $7.6 \pm 0.7 \%$ in five cells (Fig. $3 A$ ), showing that there is only minor desensitization of $\mathrm{GABA}_{\mathrm{A}}$ receptors produced by the block of GABA uptake increasing GABA levels in the slice (Overstreet et al., 2000). However, SKF89976 A greatly increased the response to GABA (Fig. 3B). Under control conditions (Fig. $3 C$ ), the ratio of the response produced by bath-applied GABA to that produced by THIP was $0.55 \pm 0.10$, but in the presence of SKF-89976A, the ratio of the responses to GABA and THIP increased to $1.57 \pm 0.16$ (significantly different from control conditions; $p=$ 0.0002 ). These data are consistent with GABA transport being reduced so that a higher GABA concentration is able to penetrate into the slice.

When ischemia solution was applied in the maintained presence of SKF-89976A (Fig. 3D), the latency and size of the AD current were not affected (Fig. $3 E, F$ ), nor was the frequency of spontaneous synaptic currents $(23.9 \pm 5.1 \mathrm{~Hz}$ in four cells; averaged over the period 3.5-4 min after the start of ischemia; $p=$ 0.57 compared with control ischemia in the absence of SKF89976A) (Fig. 1C). However, the size of the post-AD current blocked by GABAzine was reduced by $70 \%(p=0.003)$ (Fig. $3 D, G)$. Thus, much of the GABA release after the $\mathrm{AD}$ is by reversal of GAT-1.

The magnitude of the GABAzine-blocked current remaining in the presence of SKF-89976A was not significantly affected by pretreatment with concanamycin (196 $\pm 74 \mathrm{pA}$ in eight cells without and $124 \pm 44 \mathrm{pA}$ in seven cells with concanamycin pretreatment; $p=0.42$; data not shown), showing that no exocytotic component of GABA release after the $\mathrm{AD}$ was detectable even with release by reversed uptake inhibited.

Although GAT-1 is the major GABA transporter in the hippocampus, the glial transporter GAT-3 is also present (Ribak et al., 1996). To determine whether GABA is also released by reversed transport on GAT-3, we tested the effect of the GAT-3 inhibitor $\beta$-alanine. Unlike SKF-89976A, $\beta$-alanine is a lowaffinity transport substrate and a low-affinity $\mathrm{GABA}_{\mathrm{A}}$ receptor agonist, so we adopted the approach used by Rossi et al. (2000, 2003 ) to block reversed transport of glutamate or GABA (i.e., 
preloading cells with the transported inhibitor). We incubated slices for at least $1 \mathrm{hr}$ with $1 \mathrm{~mm} \beta$-alanine and then switched to solution lacking $\beta$-alanine. The aim was to accumulate $\beta$-alanine inside cells, where it will occupy the transporter and reduce transport of GABA out of the cells if the transporter is running backward (or reduce transport into the cells if the transporter is running in the forward direction). To check that $\beta$-alanine preloading succeeded in impairing GABA transport, we again compared the pyramidal cell responses to exogenous GABA and THIP. As for SKF-89976A, $\beta$-alanine preloading had little effect on the response to THIP (Fig. $4 A-C$ ), showing that $\mathrm{GABA}_{\mathrm{A}}$ receptors had not been desensitized either by $\beta$-alanine itself or by increased GABA levels in the slice because of the block of uptake, but it increased the ratio of the response produced by bathapplied GABA to that produced by THIP (Fig. $4 A, B, D$ ). However, $\beta$-alanine preloading did not greatly affect the response to ischemia (Fig. $4 E$ ): although the latency to the $\mathrm{AD}$ was slightly increased (Fig. $4 F$ ), there was no change in the amplitude of the AD current or the size of the GABAzine suppressible current (Fig. $4 G, H)$, implying that neither reversal of, nor uptake by, GAT-3 contributes significantly to regulating the extracellular GABA concentration reached after the $\mathrm{AD}$.

We conclude that most of the GABA released after the AD is via reversal of GAT-1 transporters.

\section{Ischemia-evoked GABA release still occurs in the presence of glutamate receptor blockers}

The depolarization and ion fluxes caused by activation of glutamate receptors during ischemia contribute to causing the reversal of glutamate transporters and release of glutamate (Rossi et al., 2000). To determine whether activation of glutamate receptors is necessary to cause ischemia-evoked GABA release, we recorded the response to ischemia with AMPA, kainate, and NMDA receptors blocked using $25 \mu \mathrm{M}$ NBQX, $50 \mu \mathrm{M}$ D-AP5, $50 \mu \mathrm{M}$ MK-801, and $100 \mu \mathrm{M}$ 7-chlorokynurenic acid. Ischemia then evoked a slowly developing inward current (i.e., lacking the sudden large $\mathrm{AD}$ current seen when glutamate receptors were not blocked) (Fig. 5A), with superimposed synaptic currents similar to those seen in solution lacking glutamate receptor blockers (Fig. $1 B$ ). The inward current that developed was attributable to GABA release because it was blocked by GABAzine (Fig. $5 A$ ): the GABAzine-blocked current measured at 18-20 min after the start of ischemia was $879 \pm 88 \mathrm{pA}$ in eight cells (Fig. $5 C$ ). This phase of the GABA release was primarily by reversed uptake, because repeating the experiment in the presence of SKF-89976A to block GAT-1 reduced the GABAzine-blocked current by 68\% ( $p=$ 0.0007; five cells in SKF-89976A) (Fig. 5B,C).

\section{Blocking $\mathrm{GABA}_{\mathrm{A}}$ receptors increases the $\mathrm{AD}$}

To examine the functional effects of $\mathrm{GABA}_{\mathrm{A}}$ receptor activation during ischemia, we examined the effect of blocking $\mathrm{GABA}_{\mathrm{A}}$ receptors on the voltage response and swelling of pyramidal cells induced by ischemia.

Figure $6 \mathrm{~A}$ shows the voltage response of an area CA1 pyramidal cell to simulated ischemia, recorded using gramicidinperforated patch clamping to avoid altering the intracellular chloride or calcium concentration of the cell. The initial response to ischemia was a depolarization of a few millivolts (filled arrow; $2.3 \pm 0.2 \mathrm{mV}$ in six cells) often accompanied by an increase in action potential rate, and this was then followed by a hyperpolarization below the initial resting potential (open arrow; $6.9 \pm$ $1.6 \mathrm{mV}$ in 6 cells), which always stopped action potential production. These changes may, in part, reflect a previously documented
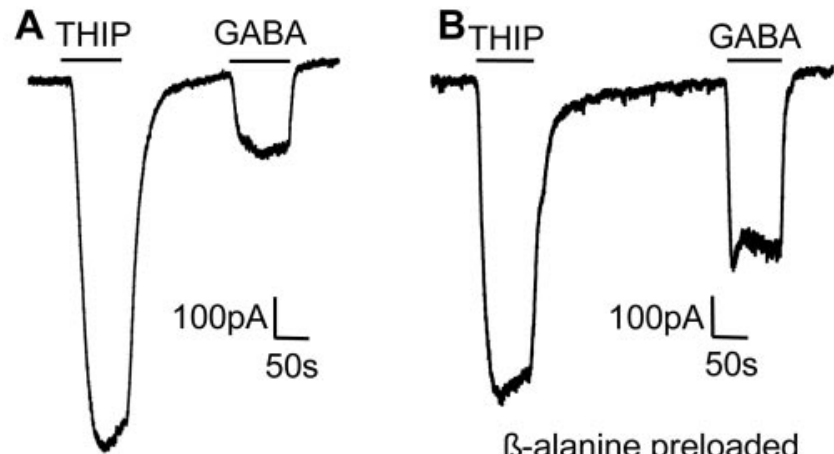

ß-alanine preloaded

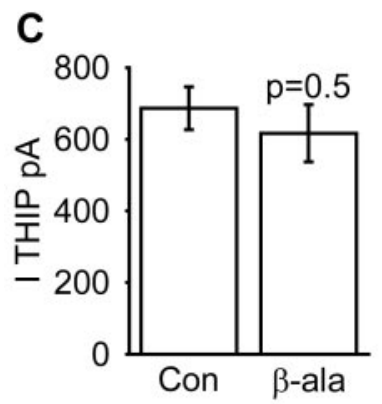

D
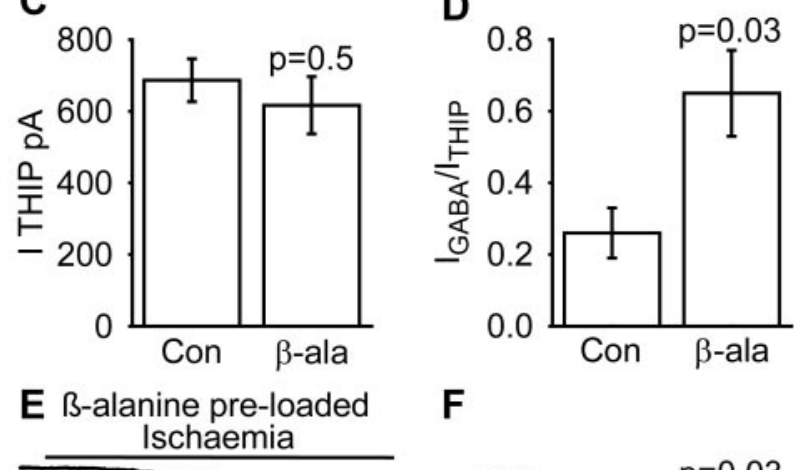

$\mathbf{F}$
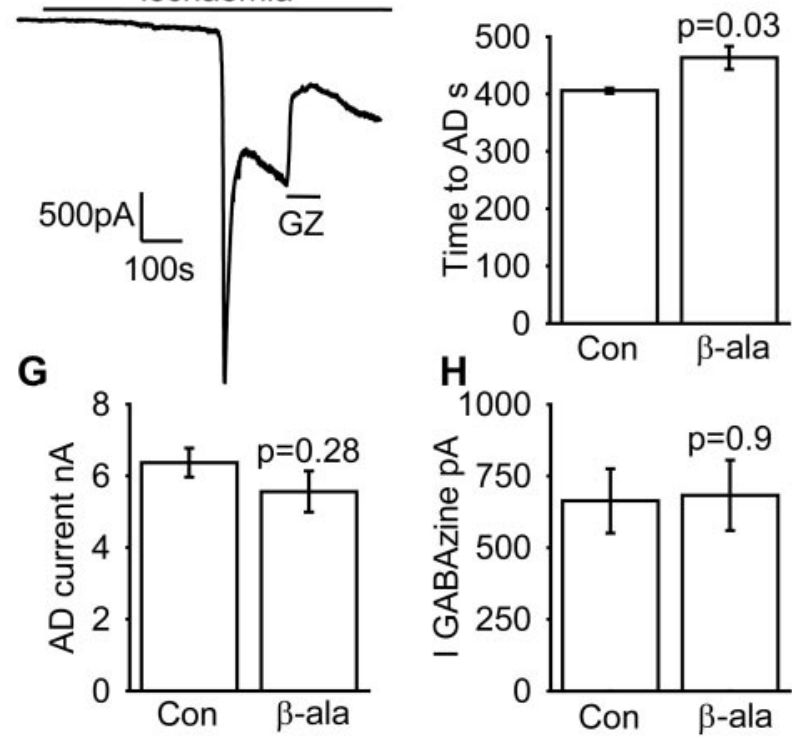

Figure 4. $\quad \beta$-Alanine preloading blocks the glial GABA transporter GAT-3 but does not reduce ischemia-evoked GABA release. $A$, Response of a pyramidal cell in an untreated slice in nonischemic solution to GABA $(10 \mu \mathrm{M})$ and to the nontransported GABA analog THIP $(20 \mu \mathrm{M}) . B$, As in $A$, but in a $\beta$-alanine-loaded slice. C, The size of the THIP response in $A$ and $B$ was not affected by $\beta$-alanine loading. $D$, The ratio of the GABA response to the THIP response increased 2.5 -fold in $\beta$-alanine-loaded slices (data from 6 control and $6 \beta$-alanine-treated interleaved slices for $C$ and $D$ ). $E$, After $\beta$-alanine loading, the response to ischemia was little affected (compare Fig. $1 A) . F$, The time to the AD was slightly prolonged in $\beta$-alanine-loaded slices (data from 7 control and $6 \beta$-alanine-loaded interleaved slices for $F-H$ ). $G$, The amplitude of the AD current was not affected by $\beta$-alanine. $H$, The size of the GABAzine-blockable current after the AD was not affected by $\beta$-alanine preloading. All data are at $-33 \mathrm{mV}$.

suppression of $\mathrm{K}^{+}$currents by $\mathrm{O}_{2}$ removal, followed by an activation of $\mathrm{Ca}^{2+}$ - and ATP-gated $\mathrm{K}^{+}$channels when [ATP] falls after metabolic inhibition (Jiang and Haddad, 1994; Jiang et al., 1994; Yamamoto et al., 1997; Nowicky and Duchen, 1998), which were not seen in the whole-cell data presented above because $\mathrm{Cs}^{+}$ 
A

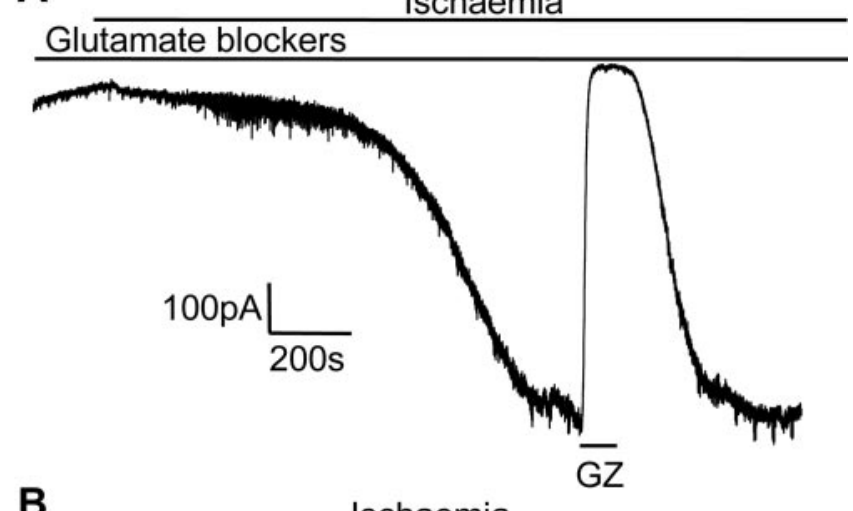

B

Ischaemia

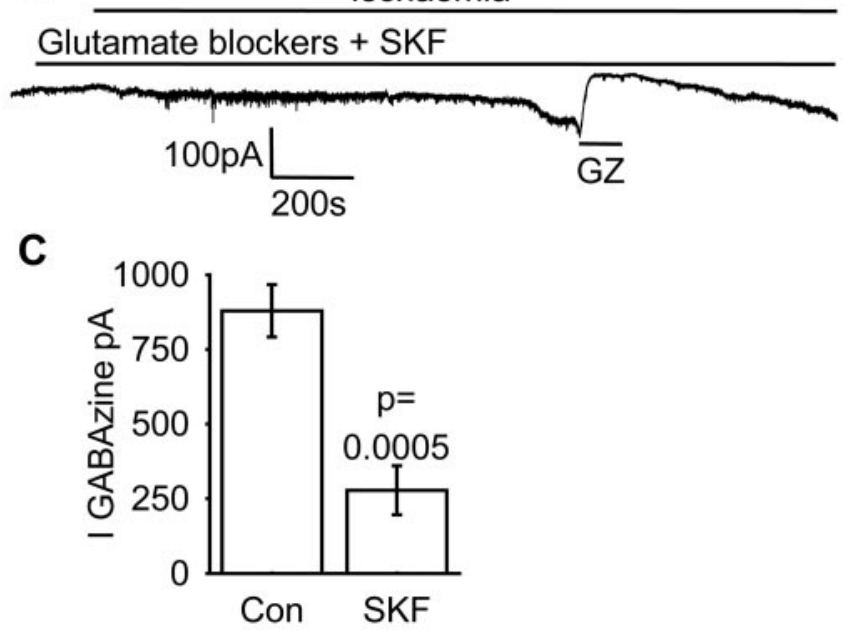

Figure 5. Blocking all ionotropic glutamate receptors does not prevent $G A B A$ release during

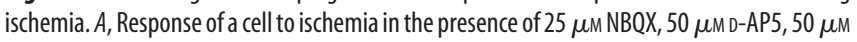
MK-801, and $100 \mu \mathrm{M}$ 7-chlorokynurenic acid to block glutamate receptors. The ischemic response was delayed, but a slow inward current developed after 10 min that was completely blocked by GABAzine, showing it to be mediated by $G_{A B A_{A}}$ receptor activation. Increased noise on the trace is spontaneous synaptic currents. $B$, With GAT-1 blocked throughout with $100 \mu \mathrm{M}$ SKF-89976A, a GABA $A_{A}$-mediated inward current still developed but the amplitude was greatly reduced, whereas spontaneous events were still seen before the AD. C, The amplitude of the GABAzine-blockable current was reduced by $68 \%$ when GAT-1 was blocked (8 cells studied in control solution, 5 interleaved cells with $100 \mu \mathrm{m}$ SKF89976A). All data are at $-33 \mathrm{mV}$.

rather than $\mathrm{K}^{+}$was inside the cell. Then, after $\sim 4$ min, a noisy depolarization developed slowly, on which occasional action potentials were superimposed, before a sudden regenerative depolarization to a voltage more positive than $-20 \mathrm{mV}$ occurred (the AD).

When this procedure was repeated with $\mathrm{GABA}_{\mathrm{A}}$ receptors blocked throughout with $10 \mu \mathrm{M}$ GABAzine (Fig. $6 \mathrm{~B}$ ), the resting potential in non-ischemic solution was not significantly different compared to control cells ( $p=0.72$ ) (Fig. 6C), and neither was the initial depolarization seen in response to ischemia (mean value, $2.7 \pm 0.4 \mathrm{mV}$ in five cells; $p=0.43$ compared with no GABAzine), nor the subsequent hyperpolarization $(7.1 \pm 2.7$ $\mathrm{mV} ; p=0.95)$, nor the increase in action potential production during the initial depolarization $(p=0.32$ ) or just before the $\mathrm{AD}$ $(p=0.9)$. However, the depolarization reached just after the $\mathrm{AD}$ was $5 \mathrm{mV}$ more positive with $\mathrm{GABA}_{\mathrm{A}}$ receptors blocked ( $p=$ 0.04) (Fig. 6D).
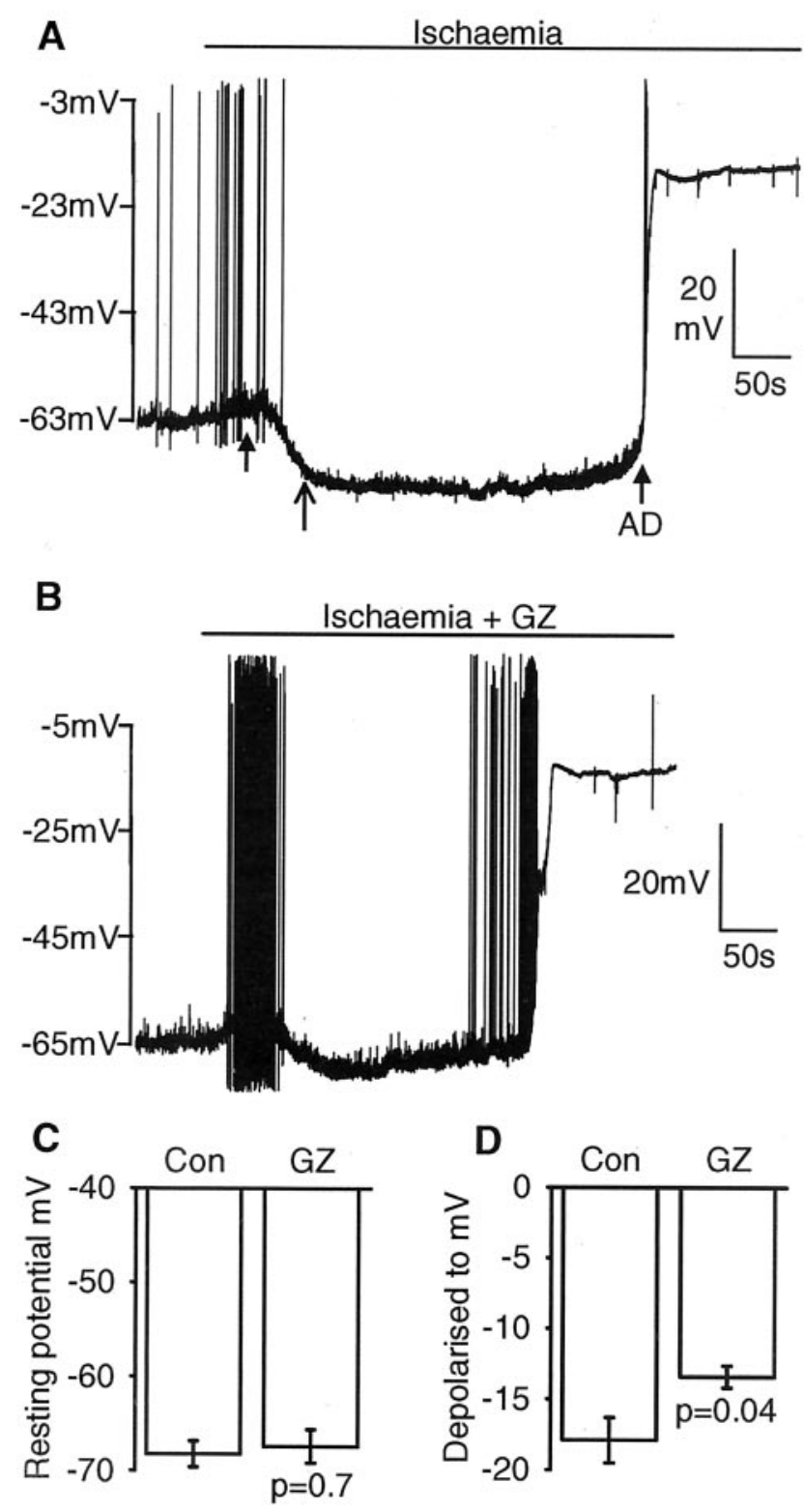

Figure 6. Blocking $\mathrm{GABA}_{A}$ receptors alters the potential reached during the response of $\mathrm{CA} 1$ pyramidal cells to ischemia. $A$, Current-clamp recording in perforated patch configuration. On application of ischemia solution, the cell deploarizes by a few millivolts (thick arrow) and then hyperpolarizes (thin arrow), then the $A D$ occurs after a few minutes. Large vertical thin lines are action potentials. $B$, As in $A$, but with $G A B A_{A}$ receptors blocked by GABAzine. C, The resting potentials of the cells studied without (control) and with GABAzine were not significantly different before ischemia. D, Cells in GABAzine deploarized more at the time of the AD ( 6 cells control, 5 cells GABAzine).

GABA release promotes cell swelling at the time of the $\mathrm{AD}$ As explained above, $\mathrm{Cl}^{-}$entry through $\mathrm{GABA}_{\mathrm{A}}$ channels is expected to promote cell swelling in ischemia. To investigate this, we used the fact that cell swelling leads to a decrease of light scattering and an increase of light transmittance through the slice (Kreisman et al., 1995; Joshi and Andrew, 2001), as schematized in Figure $7 A$. Figure $7 B$ shows a specimen record of light transmittance during application of normal ischemic solution. After 6-7 min of ischemia, there is a sudden increase of transmittance, which then decreases slowly. The sudden increase was shown, by simultaneous recording of the extracellular field potential (see Materials and Methods), to occur at the same time as the AD (Fig. 


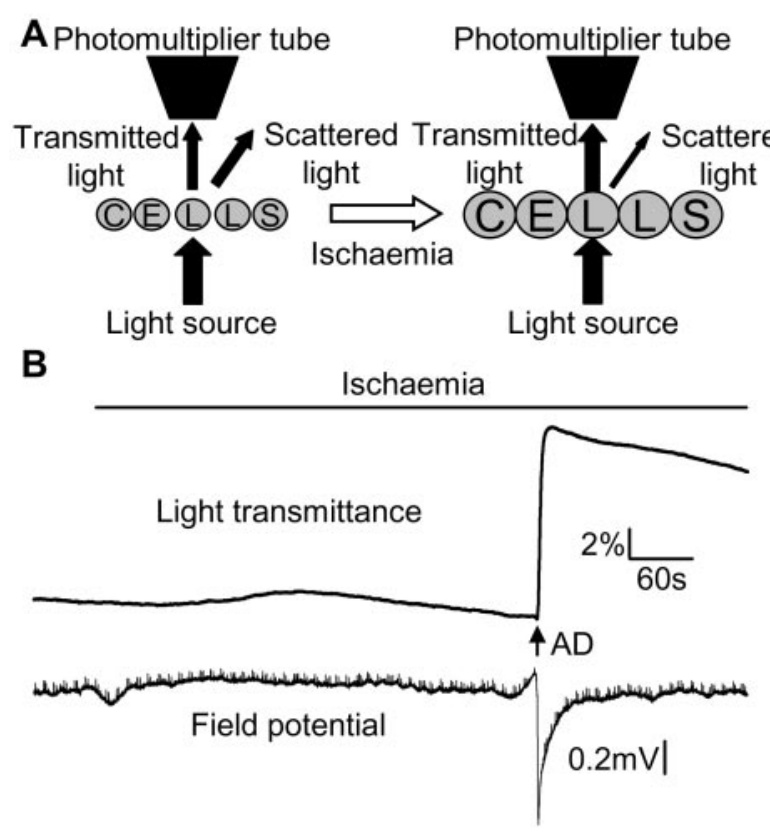

C
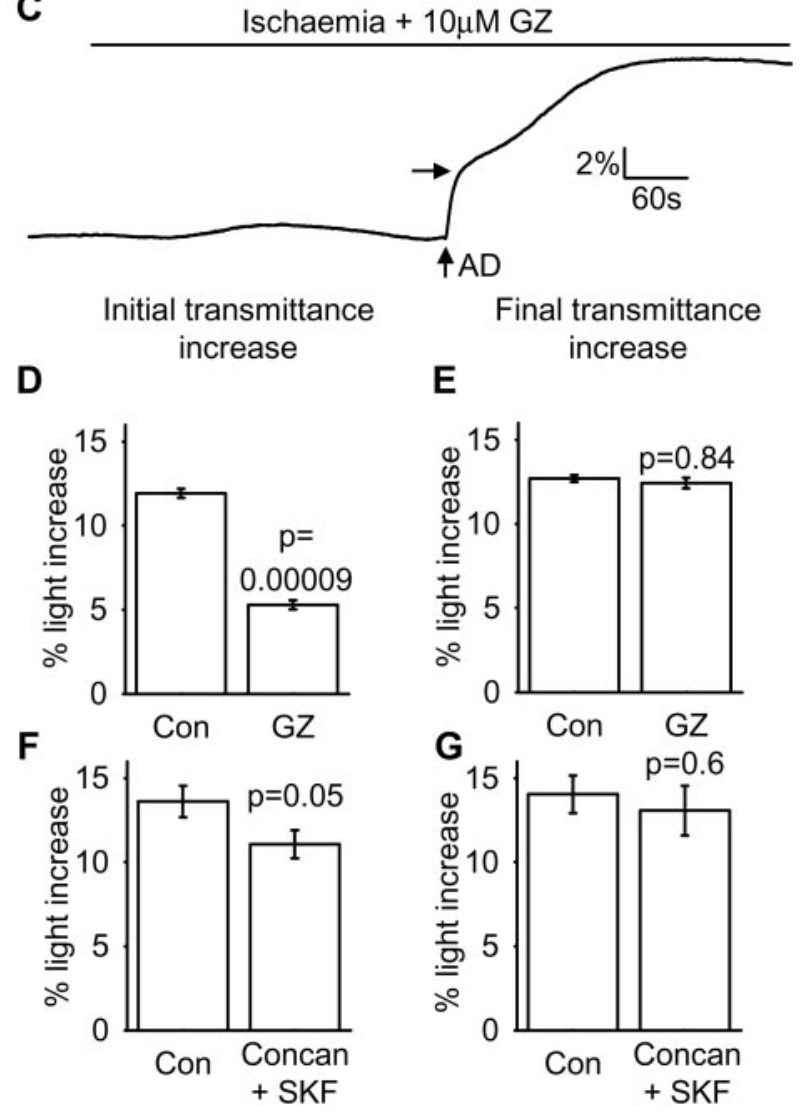

Figure 7. Activation of $G A B A_{A}$ receptors at the time of the $A D$ potentiates cell swelling. $A$, Schematic diagram of light transmittance measurement. Intracellular organelles scatter light and reduce the transmitted light. When cells swell, the organelles are diluted, reducing scattering and increasing transmittance. $B$, Light levels transmitted through a slice remained constant until the time of the $A D$, when there was a sudden increase in transmittance attributed to cellular swelling. The bottom trace shows the extracellularly recorded field potential for correlation of the timing of swelling and of the $A D$. $C$, With $G A B A_{A}$ receptors blocked, the initial increase in light transmittance (marked by a horizontal arrow) at the time of the AD was reduced, but transmittance continued to increase slowly over a number of minutes. $D$, The initial light increase at the time of the $A D$ was reduced in GABAzine (8 slices control ischemia solution,
$7 B$ ), and the increase measured $5 \mathrm{~min}$ after the $\mathrm{AD}$ was correlated with a $43 \%$ increase of the soma diameter (see Materials and Methods).

When this experiment was performed in the presence of GABAzine (Fig. $7 C$ ), the initial rapid increase of transmittance was reduced to less than half (Fig. 7D), although the final level of transmittance reached after several minutes was unaffected (Fig. $7 E)$. This suggests that with $\mathrm{GABA}_{\mathrm{A}}$ receptors blocked there is less initial swelling when glutamate depolarizes cells at the time of the $\mathrm{AD}$, presumably because $\mathrm{Cl}^{-}$can enter less readily, but that slower $\mathrm{Cl}^{-}$entry through routes other than $\mathrm{GABA}_{\mathrm{A}}$ receptors (yet to be determined) eventually results in a similar amount of swelling occurring. Blocking GABA release with a combination of concanamycin pretreatment and SKF-89976A also reduced the initial phase of the swelling (Fig. $7 F, G$ ), but by less than was seen with the block of $\mathrm{GABA}_{\mathrm{A}}$ receptors, presumably because concanamycin and SKF-89976A do not completely block GABA release (compare the incomplete block of the GABAzinesuppressed current in Figs. 3G and 5C).

\section{$\mathrm{GABA}_{\mathrm{A}}$ receptors become inactivated after the $\mathrm{AD}$ by $\mathrm{Ca}^{2+}$ entry through NMDA receptors}

Since glutamate released after the AD activates NMDA receptors (Rossi et al., 2000) and $\mathrm{Ca}^{2+}$ entry through NMDA receptors is known to reduce the activity of $\mathrm{GABA}_{\mathrm{A}}$ receptors (Inoue et al., 1986; Stelzer and Shi, 1994; Chen and Wong, 1995), we were interested in whether inactivation of $\mathrm{GABA}_{\mathrm{A}}$ receptors after the $\mathrm{AD}$ might explain the lack of effect of GABAzine on swelling 5 min after the AD (Fig. 7E).

The whole-cell clamp data in Figures 1-5 were obtained using BAPTA as the calcium buffer in the pipette. In this situation, applying GABAzine or GABA after the $\mathrm{AD}$ generated an outward or inward current, respectively (Fig. $8 A, D$ ). When the slower buffer EGTA with $0.5 \mathrm{mM} \mathrm{Ca}^{2+}$ was used, GABA did evoke a current if applied before ischemia $(1.9 \pm 0.3 \mathrm{nA}$ peak current on application of $100 \mu \mathrm{M}$ GABA; four cells; data not shown), but GABAzine and GABA evoked no current after the AD (Fig. $8 B, C, E, F$ ), and the post-AD plateau current was smaller (Fig. $8 G$ ), suggesting that the contribution of $\mathrm{GABA}_{\mathrm{A}}$ receptors to the plateau was missing.

We blocked NMDA receptors with MK-801 (50 $\mu \mathrm{M})$ to see whether that would preserve $G_{A B A}$ receptor function even when using EGTA as a buffer (Fig. $8 H$ ). MK-801 prolonged the latency to the $\mathrm{AD}$ by $1.5 \mathrm{~min}$ ( $p=0.02$; seven cells without and eight cells with MK-801) (Fig. 8I) and reduced the AD current amplitude by $36 \%(p=0.01$; Fig. $8 J)$, consistent with NMDA receptors playing a major role in generating the $\mathrm{AD}$ (Rossi et al., 2000). In this situation, GABAzine was again able to evoke a current change after the $\mathrm{AD}$ (Fig. $8 \mathrm{H}, \mathrm{K}$ ), which was almost as large as that seen using a BAPTA-based internal solution (Fig. $8 C$ ). Thus, the lack of a GABAzine-blocked current in Figure $8 B$ does not reflect a lack of ischemia-evoked GABA release into the slice when EGTA is used in the pipette clamping the sensing cell (indeed, GABA release is presumably from surrounding interneurons that do not have their internal solution composition

8 interleaved slices with GABAzine). $E$, The final increase in light transmittance, measured 5 min after the $A D$, was unchanged in the presence of $G A B A z i n e . F$, The initial light increase at the time of the $A D$ was reduced by pretreating slices with $0.5 \mu \mathrm{m}$ concanamycin and applying $100 \mu \mathrm{m}$ SKF-89976A throughout (14 slices control ischemia, 15 interleaved slices with concanamycin plus SKF-89976A). G, The final increase in light transmittance, measured 5 min after the AD, was unchanged by treatment with concanamycin and SKF-89976A. 

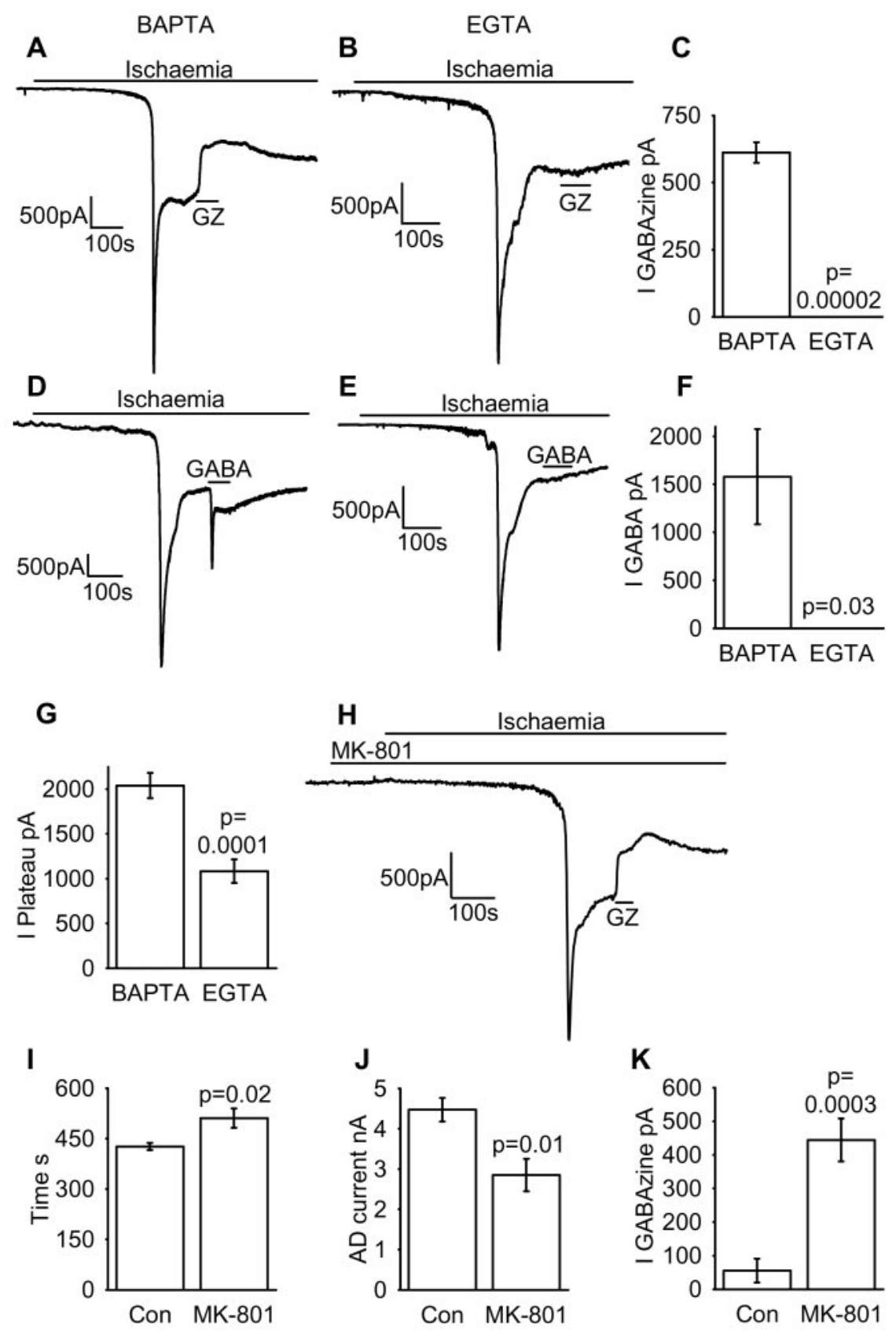

Figure 8. $G A B A_{A}$ receptors become nonfunctional after the $A D$ as a result of $C a^{2+}$ entry through NMDA receptors. $A$, Response to ischemia of a cell whole-cell clamped with BAPTA as the internal calcium buffer: GABAzine reduces the inward plateau current after the AD. B, Response to ischemia of a cell whole-cell clamped with EGTA as the calcium buffer: GABAzine has no effect on the plateau current. C, Mean GABAzine-blockable current after the AD when cells were dialyzed with BAPTA (6 cells) or with EGTA internal solution (8 interleaved cells). D, Using BAPTA, a cell responds to exogenous $1 \mathrm{~mm}$ GABA after the AD. E, Using EGTA a cell does not respond to GABA after the AD. F, Mean GABA-evoked current after the AD when cells were dialyzed with BAPTA (5 cells) or with EGTA internal solution (5 cells). G, The amplitude of the plateau current after the AD was halved when EGTA was used as the calcium buffer (10 cells dialyzed with EGTA, 10 interleaved cells with BAPTA). H, Blocking NMDA receptors with $50 \mu$ m MK-801 throughout ischemia in a cell whole-cell clamped with EGTA internal solution allows a GABAzine-blockable current to remain after the AD. I, MK-801 delayed the AD (7 EGTA cells in control solution, 8 interleaved EGTA cells with MK-801). J, MK-801 decreased the amplitude of the AD current. K, Mean GABAzine-blocked current after the AD with EGTA internal was rescued by MK-801. All data are at $-33 \mathrm{mV}$.

altered) but reflects a loss of $\mathrm{GABA}_{\mathrm{A}}$ receptor function in the sensing cell (Fig. $8 D-F)$. This implies that, in vivo, the $\mathrm{Ca}^{2+}$ influx through NMDA receptors could severely reduce the effect of GABA release after the $\mathrm{AD}$ if the calcium-buffering power of the cell is weak.

To test whether the endogenous calcium buffering of the cell is, in fact, high enough to allow $\mathrm{GABA}_{\mathrm{A}}$ receptors to function after the $\mathrm{AD}$, we used voltage clamping in the gramicidinperforated patch mode that, unlike wholecell clamping, allows us to record $\mathrm{GABA}_{\mathrm{A}}$ receptor-mediated currents without perturbing the normal intracellular calcium buffering. Ischemia evoked an outward current of mean amplitude $243 \pm 24 \mathrm{pA}$ in 23 cells (Fig. 9A), which was sometimes preceded by a small transient inward current at the time of the initial depolarization seen in Figure $6(35.5 \pm 6.5$ pA in 15 of 23 cells). The outward current was reduced to $95 \pm 23 \mathrm{pA}$ (six cells; data not shown) if GABAzine was present throughout the ischemic episode $(p=0.0003$ compared with no GABAzine), consistent with activation of $\mathrm{GABA}_{\mathrm{A}}$ receptors by exocytotic GABA release before the AD. (This $\mathrm{GABA}_{\mathrm{A}}$-mediated outward current is not evident as a voltage change before the AD in Fig. 6 because the chloride reversal potential is close to the resting potential). The outward current was followed by a large inward $\mathrm{AD}$ current $(\sim 1.3 \mathrm{nA}$, smaller than the $\sim 5 \mathrm{nA}$ seen in the wholecell mode because of the much higher series resistance inherent in perforated patch recording), which then decreased to a maintained plateau (Fig. 9A).

Applying GABAzine 2 min after the AD evoked no current change in four cells (Fig. 9A). Because there is some uncertainty about the value of the chloride reversal potential at this time (Inglefield and Schwartz-Bloom, 1998) and $\mathrm{E}_{\mathrm{Cl}}$ could theoretically, by chance, have moved to be near our holding potential of $-33 \mathrm{mV}$, in two of the four cells studied we also applied voltage steps to check whether a GABAzine-blocked current occurred at any potential. No change in current was produced by GABAzine at potentials between -23 and $-63 \mathrm{mV}$ (Fig. 9B). In another four cells that went to the whole-cell mode after the AD, allowing BAPTAcontaining medium to enter the cell (which would normally have sustained $\mathrm{GABA}_{\mathrm{A}}$ receptor function), we also found no GABAzine-blocked current (Fig. $9 C, D)$, probably because the rise of calcium occurring at the time of the $\mathrm{AD}$ leads to a long-lasting suppression of $\mathrm{GABA}_{\mathrm{A}}$ receptor function. [Stelzer and Shi (1994) showed that the suppression produced by high $\mathrm{Ca}^{2+}$ loads can last for $<60 \mathrm{~min}$.

Thus, although ischemia leads to a large release of GABA, and although and activation of $\mathrm{GABA}_{\mathrm{A}}$ receptors reduces the $\mathrm{AD}$ (Fig. $6 D$ ) and increases cell swelling just after the $\mathrm{AD}$ (Fig. $7 D$ ), a few minutes later $\mathrm{GABA}_{\mathrm{A}}$ receptors are inactivated by calcium that enters through NMDA receptor channels. 

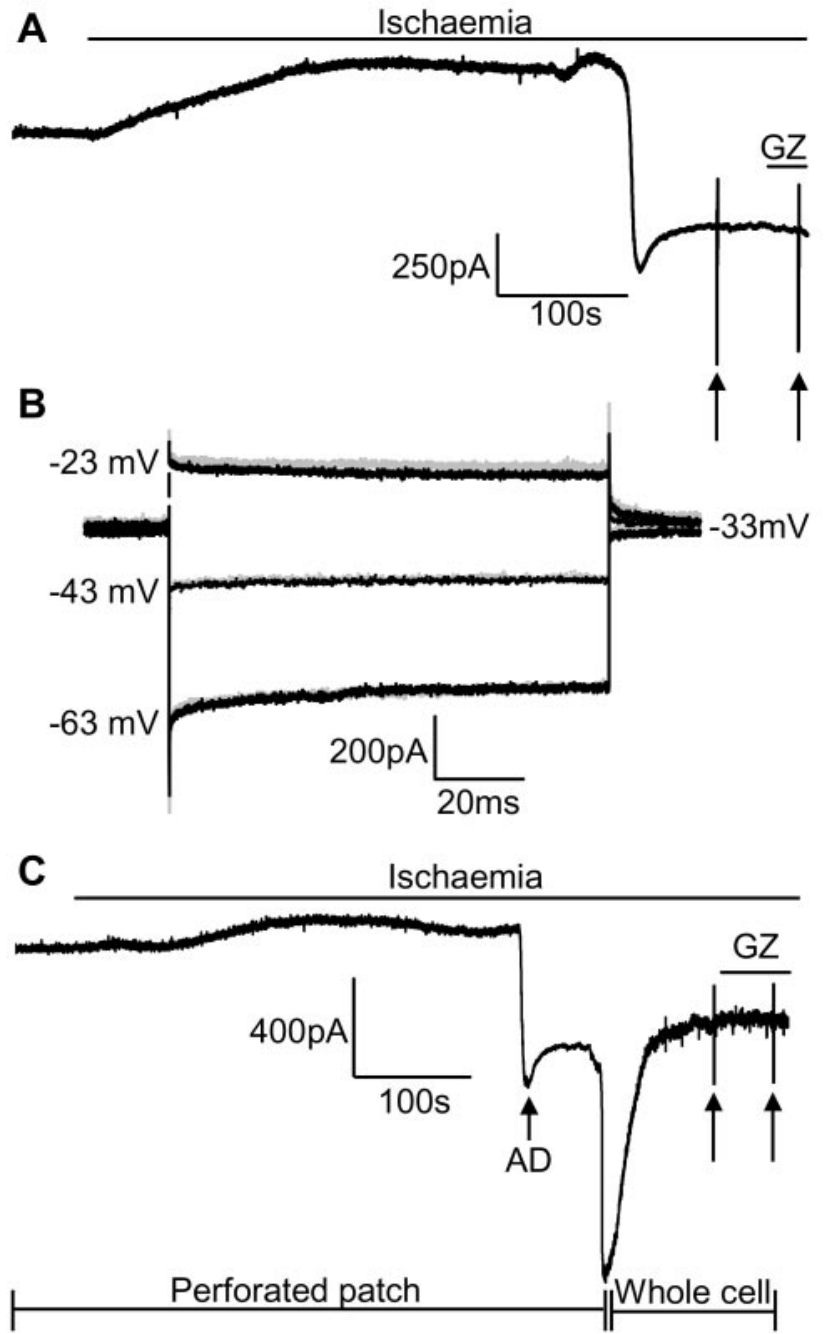

D

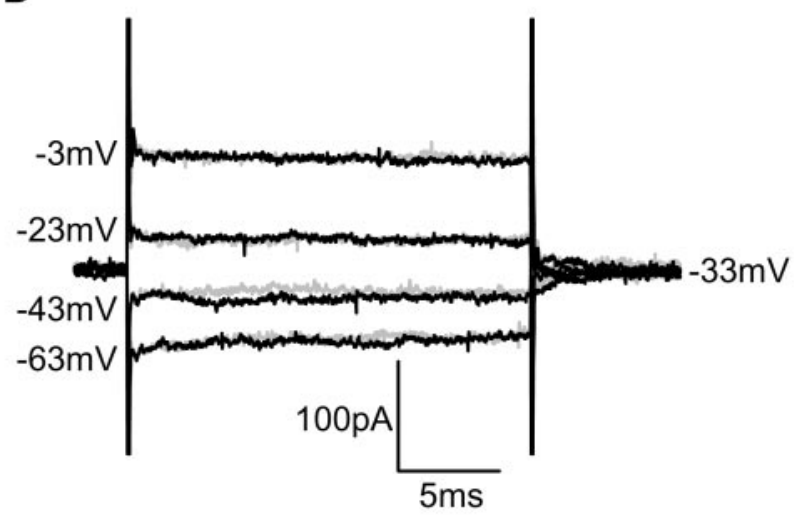

Figure 9. $G A B A_{A}$ receptors are inactivated after the $A D$ in $C A 1$ neurons when the internal calcium buffering of the cell is not altered by whole-cell clamping. $A$, Recording of a CA1 neuron at $-33 \mathrm{mV}$ in the perforated-patch mode, showing no response to the application of GABAzine 2 min after the $A D$; arrows mark two sets of voltage steps applied before and in GABAzine. $B$, Current responses to voltage steps applied before GABAzine (black lines) and in GABAzine (gray lines). The two sets of traces superimpose, showing that the lack of response to GABAzine seen at $-33 \mathrm{mV}$ in $A$ is not attributable to the chloride reversal potential being close to $-33 \mathrm{mV}$ ( 4 cells had GABAzine applied, and two of these were stepped to different potentials as here). $C, D$, $G A B A_{A}$ receptors remain desensitized after the $A D$, after going to the whole-cell mode from the perforated-patch mode with a BAPTA-buffered internal solution. C, Cell recorded in the perforated-patch mode at $-33 \mathrm{mV}$; the first large inward deflection is the $A D$ current, and the second is the cell shifting from the perforated to the whole-cell mode (as assessed by the entry

\section{Discussion}

We have explored (1) the mechanisms of GABA release in ischemia (using a whole-cell pipette solution with high $\mathrm{Ca}^{2+}$ buffering power to preserve the function of the $\mathrm{GABA}_{\mathrm{A}}$ receptors used to sense released GABA), (2) the effects that $\mathrm{Ca}^{2+}$ influx through NMDA receptors might have on $\mathrm{GABA}_{\mathrm{A}}$-mediated currents (using a pipette solution of lower $\mathrm{Ca}^{2+}$-buffering power), and (3) the effects that NMDA receptor-mediated $\mathrm{Ca}^{2+}$ influx actually has (using perforated patch recording).

\section{Ischemia evokes GABA release by two separate sequential mechanisms}

Ischemia evokes GABA release initially by an increased frequency of exocytotic events (Fig. 1) and later, after the run-down of ion gradients associated with the $\mathrm{AD}$, by reversed operation of neuronal GABA transporters (Fig. 3). The same sequence of release modes occurs for ischemia-evoked glutamate release (Katchman and Hershkowitz, 1993; Rossi et al., 2000). Thus, exocytotic release is more sensitive than transporter-mediated release to the energy deprivation induced by ischemia, possibly because vesicle release is increased by a small rise of $\left[\mathrm{Ca}^{2+}\right]_{i}$ early in the rundown of ion gradients that occurs in ischemia (Tanaka et al., 1997, their Fig. 2), whereas reversal of transporters requires that there is time for a larger run-down of transmembrane ion gradients to occur (Attwell et al., 1993).

There may also be some GABA release by reversed uptake before the AD. This cannot be rigorously quantified by the application of SKF-89976A because, although this blocks release by reversal of GAT-1, it will also (by preventing GABA uptake) increase the effect of the GABA being released by exocytosis at this time.

The size of the GABA-mediated current $1 \mathrm{~min}$ before the $\mathrm{AD}$ $(\sim 130$ pA) (Fig. $1 D)$ was only $20 \%$ of that after the AD $(\sim 610$ pA) (Fig. 2), showing that more GABA is released after the $\mathrm{AD}$ than before it.

GABA is released after the AD by reversal of neuronal, but not glial, transporters

GABA transporters are powered by the cotransport of $2 \mathrm{Na}^{+}$and $1 \mathrm{Cl}^{-}$ions (Richerson and $\mathrm{Wu}, 2003$ ) and so have less accumulative power than glutamate transporters that cotransport $3 \mathrm{Na}^{+}$ and $1 \mathrm{H}^{+}$and counter-transport $1 \mathrm{~K}^{+}$(Zerangue and Kavanaugh, 1996; Levy et al., 1998). Consequently, GABA transporters reverse readily when the membrane is depolarized or intracellular GABA concentrations rise (Gaspary et al., 1998; Wu et al., 2001; Richerson and $\mathrm{Wu}, 2003)$.

Inhibition of GAT-1 (but not GAT-3) transporters reduced ischemia-evoked GABA release by reversed uptake after the $\mathrm{AD}$ (Figs. 3, 4). GAT-1 is mainly in interneurons (particularly synaptic terminals) whereas GAT-3 is glial (Ribak et al., 1996), so this difference could reflect a faster run-down of ion gradients in neurons than in glia, or a higher $[\mathrm{GABA}]_{\mathrm{i}}$ in neurons than in glia, which would preferentially promote the reversal of neuronal transporters. $[\mathrm{GABA}]_{\mathrm{i}}$ increases during ischemia (Erecinska et al., 1984; Madl and Royer, 2000) because low [ATP] stimulates

$\leftarrow$

of Lucifer yellow into the cell). Application of GABAzine did not affect the plateau current, despite the presence of BAPTA inside the cell. D, Current response to voltage steps applied before GABAzine (black lines) and in GABAzine (gray lines). The two sets of traces superimpose, showing that the lack of response to GABAzine in C is not attributable to the chloride reversal potential shifting to be at $-33 \mathrm{mV}$ (done in 4 cells). 
GABA synthesis by glutamate decarboxylase, the acidic intracellular $\mathrm{pH}$ occurring in ischemia inhibits GABA breakdown by GABA transaminase, and loss of vesicular GABA (after the vesicular $\mathrm{H}^{+}$-ATPase is inhibited when [ATP] falls) may raise the cytoplasmic $[\mathrm{GABA}]$. The increase in $[\mathrm{GABA}]_{\mathrm{i}}$ is primarily in neuronal terminals, rather than glia (Torp et al., 1993; Madl and Royer, 2000), so the rise of [GABA $]_{i}$ produced by these mechanisms will preferentially promote the reversal of the neuronal GAT-1.

\section{Exocytosis is not a significant GABA release mechanism after the AD}

Depletion of GABA from vesicles with concanamycin did not affect the GABA-mediated current after the AD (Fig. 2). Similarly, the ischemia-evoked release of glutamate after the AD is not affected by preventing glutamate exocytosis (Rossi et al., 2000). Because the high $\left[\mathrm{Ca}^{2+}\right]_{\mathrm{i}}$ after the AD would normally be expected to trigger exocytosis, these results suggest that exocytotic release is inhibited after the AD. This could be because vesicles are depleted of transmitter as a result of [ATP] falling and inhibiting the vesicular $\mathrm{H}^{+}$-ATPase, so that although vesicles can still fuse with the surface membrane, they no longer contain transmitter, or it could reflect a depletion of releasable vesicles as a result of the increase in exocytotic release before the AD. Alternatively, if vesicle trafficking or refilling depend critically on G-protein signaling (Takahashi et al., 2000), then the fall of [ATP] and [GTP] in ischemia may directly inhibit exocytosis.

\section{Activation of glutamate receptors is not essential for reversal of GAT-1 to occur}

The large GABA-mediated current evoked by ischemia in the presence of glutamate receptor blockers develops more slowly than the inward current (mediated in part by glutamate receptors) seen at the time of the $\mathrm{AD}$ in the absence of the blockers, suggesting that glutamate release is important for increasing the rate of rundown of the ion gradients of the cells and producing the normal explosive AD (Rossi et al., 2000). Nevertheless, even with glutamate receptors blocked to prevent glutamate-evoked depolarization and ion fluxes, the transmembrane ion gradients do eventually run down sufficiently to reverse the operation of GABA transporters (Fig. 5).

\section{The effects of ischemia-evoked GABA release}

Ischemia-evoked GABA release and activation of $\mathrm{GABA}_{\mathrm{A}}$ receptors led to larger rapid cell swelling at the time of the $\mathrm{AD}$ (Fig. 7), presumably because when glutamate, released by ischemia, depolarizes neurons, a $\mathrm{Cl}^{-}$influx through $\mathrm{GABA}_{\mathrm{A}}$ receptor channels allows an osmotic gradient to build up, which promotes water influx. This is expected to produce most damage in small dendrites in which the surface to volume ratio is high. Such damage may occur preferentially in animals older than the postnatal day 12 rats used here, because the inhibitory input to the dendrites of pyramidal cells develops later than that to the soma region (Banks et al., 2002).

GABA release during ischemia has been hypothesized to keep cells hyperpolarized (although $\mathrm{GABA}_{\mathrm{A}}$ responses can be depolarizing) (Staley et al., 1995; Gulledge and Stuart, 2003) and thus counteract effects that lead to neuronal death (Saransaari and Oja, 1997). Indeed, GABA release could be protective before the $\mathrm{AD}$ by increasing inhibition and could potentially prevent the $\mathrm{AD}$ from occurring during less severe episodes of ischemia. However, although activation of $\mathrm{GABA}_{\mathrm{A}}$ receptors was indeed found to reduce the size of the $\mathrm{AD}$ (Fig. 6), our swelling data (Fig. 7) suggest that GABA release may be actively harmful during the ischemic insult. This is consistent with the block of $\mathrm{GABA}_{\mathrm{A}}$ receptors reducing the death of retinal and cerebellar granule neurons evoked by activation of glutamate receptors (Chen et al., 1999) and with the block of GAT-1 reducing glutamate-evoked GABA release (presumably by reversed uptake) and cell swelling in the retina (Zeevalk and Nicklas, 1996) and reducing ischemiaevoked neuronal death in vivo (Phillis, 1995).

The block of $\mathrm{GABA}_{\mathrm{A}}$ receptors did not affect the amount of swelling occurring several minutes after the $\mathrm{AD}$ because of the ischemia-evoked inactivation of $\mathrm{GABA}_{\mathrm{A}}$ receptors (see below). Thus, blocking $\mathrm{GABA}_{\mathrm{A}}$ receptors delays swelling but does not abolish it (presumably because $\mathrm{Cl}^{-}$can enter cells via other channels). The significance of this for ischemia-evoked damage is uncertain, but it is possible that the cytoskeleton could adapt better to slow than to fast swelling.

\section{Termination of the effects of GABA by $\mathrm{Ca}^{2+}$ entry through NMDA receptors}

Although GABA release affects the membrane potential reached during the $\mathrm{AD}$ (Fig. 6) and generates cell swelling around the time of the $\mathrm{AD}$ (Fig. 7), calcium influx through NMDA receptors inactivates $\mathrm{GABA}_{\mathrm{A}}$ receptors a few minutes after the $\mathrm{AD}$ (Figs. 8, 9) and thus prevents further swelling evoked by GABA-evoked $\mathrm{Cl}^{-}$ entry. Alicke and Schwartz-Bloom (1995) found ischemia decreases the surface expression of $\mathrm{GABA}_{\mathrm{A}}$ receptors in $\mathrm{CA} 1 \mathrm{neu}$ rons, so internalization of $\mathrm{GABA}_{\mathrm{A}}$ receptors may underlie the lack of $\mathrm{GABA}_{\mathrm{A}}$ responsiveness after the $\mathrm{AD}$. This long-lasting inactivation ( $>1 \mathrm{hr}$ for high-calcium loads) (Stelzer and Shi, 1994) may lead to an abnormal excitability occurring after ischemia. Conversely, a therapeutic block of $\mathrm{Ca}^{2+}$ influx through NMDA receptors might (by preserving $\mathrm{GABA}_{\mathrm{A}}$ receptor function) potentiate ischemia-evoked swelling and cell damage but preserve inhibition after a brief ischemic episode.

\section{Implications for the effects of GABAergic drugs on the events of ischemia}

Potentiation of GABAergic transmission has been suggested as a treatment for reducing ischemic damage (Green et al., 2000), but our data show that the timing of such an increase of inhibition is important. Prophylactically potentiating GABAergic inhibition in patients at risk of stroke should increase the swelling-mediated damage that their neurons suffer at the onset of energy deprivation. In contrast, potentiating GABAergic transmission after an ischemic insult could reduce over-excitation caused by a potentiation of glutamatergic transmission triggered by the ischemic insult (for review, see Szatkowski and Attwell, 1994) and thus be neuroprotective (except in newborn patients in whom $\mathrm{E}_{\mathrm{Cl}}$ may be positive to the resting potential so that GABA is excitatory) (Lukasiuk and Pitkanen, 2000; Ben-Ari, 2002). Because much of the GABA release during ischemia is by reversed uptake, nontransported GABA transport blockers should be neuroprotective whether applied during or after the ischemic insult. Before the $\mathrm{AD}$, they will potentiate the effect of vesicularly released GABA; after the $\mathrm{AD}$, they will reduce GABA release and reduce the early rapid cell swelling; after the insult, they will potentiate the inhibitory actions of GABA.

\section{References}

Aika Y, Ren JQ, Kosaka K, Kosaka T (1994) Quantitative analysis of GABAlike-immunoreactive and parvalbumin-containing neurons in the CA1 region of the rat hippocampus using a stereological method, the disector. Exp Brain Res 99:267-276. 
Akaike N (1996) Gramicidin perforated patch recording and intracellular chloride activity in excitable cells. Prog Biophys Mol Biol 65:251-264.

Alicke B, Schwartz-Bloom RB (1995) Rapid down-regulation of GABA receptors in the gerbil hippocampus following transient cerebral ischaemia. J Neurochem 65:2808-2811.

Ankarcrona M, Dypbukt JM, Bonfoco E, Zhivotovsky B, Orrenius S, Lipton SA, Nicotera P (1995) Glutamate-induced neuronal death: a succession of necrosis or apoptosis depending on mitochondrial function. Neuron 15:961-973.

Attwell D, Barbour B, Szatkowski M (1993) Nonvesicular release of neurotransmitter. Neuron 11:401-407.

Bai D, Zhu G, Pennefather P, Jackson MF, MacDonald JF, Orser BA (2001) Distinct functional and pharmacological properties of tonic and quantal inhibitory postsynaptic currents mediated by gamma-aminobutyric acid(A) receptors in hippocampal neurons. Mol Pharmacol 59(4):814-824.

Banks MI, Hardie JB, Pearce RA (2002) Development of GABA A receptormediated inhibitory postsynaptic currents in hippocampus. J Neurophysiol 88:3097-3107.

Ben-Ari Y (2002) Excitatory actions of GABA during development: the nature of the nurture. Nat Rev Neurosci 3:728-739.

Borden LA, Murali Dhar TG, Smith KE, Weinshank RL, Branchek TA, Gluchowski C (1994) Tiagabine, SK\&F 89976-A, CI-966, and NNC-711 are selective for the cloned GABA transporter GAT-1. Eur J Pharmacol 269:219-224.

Chen Q, Moulder K, Tenkova T, Hardy K, Olney JW, Romano C (1999) Excitotoxic cell death dependent on inhibitory receptor activation. Exp Neurol 160:215-225.

Chen QX, Wong RKS (1995) Suppression of $\mathrm{GABA}_{\mathrm{A}}$ receptor responses by NMDA application in hippocampal neurones acutely isolated from the adult guinea pig. J Physiol (Lond) 482:353-362.

Choi DW (1987) Ionic dependence of glutamate neurotoxicity. J Neurosci $7: 369-379$.

Choi DW, Rothman SM (1990) The role of glutamate neurotoxicity in hypoxic-ischemic neuronal death. Annu Rev Neurosci 13:171-182.

De Simoni A, Griesinger CB, Edwards FA (2003) Development of rat CA1 neurones in acute versus organotypic slices: role of experience in synaptic morphology and activity. J Physiol (Lond) 550:135-147.

Djali S, Dawson LA (2001) Characterization of endogenous amino acid efflux from hippocampal slices during chemically-induced ischemia. Neurochem Res 26:135-143.

Dröse S, Altendorf K (1997) Bafilomycins and concanamycins as inhibitors of V-ATPases and P-ATPases. J Exp Biol 200:1-8.

Erecinska M, Nelson D, Wilson DF, Silver IA (1984) Neurotransmitter amino acids in the CNS. I. Regional changes in amino acid levels in rat brain during ischemia and reperfusion. Brain Res 304:9-22.

Fleidervish IA, Gebhardt C, Astman N, Gutnick MJ, Heinemann U (2001) Enhanced spontaneous transmitter release is the earliest consequence of neocortical hypoxia that can explain the disruption of normal circuit function. J Neurosci 21:4600-4608.

Fujimura M, Morita-Fujimura Y, Murakami K, Kawase M, Chan PH (1998) Cytosolic redistribution of cytochrome $\mathrm{c}$ after transient focal cerebral ischemia in rats. J Cereb Blood Flow Metab 18:1239-1247.

Gaspary HL, Wang W, Richerson GB (1998) Carrier-mediated GABA release activates GABA receptors on hippocampal neurons. J Neurophysiol 80:270-281.

Goldman MP, Choi DW (1993) Combined oxygen and glucose deprivation in cortical cell culture: calcium-dependent and calcium-independent mechanisms of neuronal injury. J Neurosci 13:3510-3524.

Green AR, Hainsworth AH, Jackson DM (2000) GABA potentiation: a logical pharmacological approach for the treatment of acute ischaemic stroke. Neuropharmacol 39:1483-1494.

Gulledge AT, Stuart GJ (2003) Excitatory actions of GABA in the cortex. Neuron 37:299-309.

Hagberg H, Lehmann A, Sandberg M, Nystrom B, Jacobson I, Hamberger A (1985) Ischemia-induced shift of inhibitory and excitatory amino acids from intra- to extracellular compartments. J Cereb Blood Flow Metab 5:413-419.

Hamann M, Rossi DJ, Marie H, Attwell D (2002) Knocking out the glial glutamate transporter GLT-1 reduces glutamate uptake but does not affect hippocampal glutamate dynamics in early simulated ischaemia. Eur J Neurosci 15:308-314.
Hansen AJ (1985) Effect of anoxia on ion distribution in the brain. Physiol Rev 65:101-148.

Inglefield JR, Schwartz-Bloom RD (1998) Optical imaging of hippocampal neurons with a chloride-sensitive dye: early effects of in vitro ischemia J Neurochem 70:2500-2509.

Inoue M, Oomura Y, Yakushiji T, Akaike N (1986) Intracellular calcium ions decrease the affinity of the GABA receptor. Nature 324:156-158.

Jiang C, Haddad GG (1994) Oxygen deprivation inhibits a $\mathrm{K}^{+}$channel independently of cytosolic factors in rat central neurons. J Physiol (Lond) 481:15-26.

Jiang C, Sigworth FJ, Haddad GG (1994) Oxygen deprivation activates an ATP-inhibitable $\mathrm{K}^{+}$channel in substantia nigra neurons. J Neurosci 14:5590-5602.

Joshi I, Andrew RD (2001) Imaging anoxic depolarization during ischemialike conditions in the mouse hemi-brain slice. J Neurophysiol $85: 414-424$.

Katchman AN, Hershkowitz N (1993) Early anoxia-induced vesicular glutamate release results from mobilization of calcium from intracellular stores. J Neurophysiol 70:1-7.

Kemp JA, Marshall GR, WoodruffGN (1986) Quantitative evaluation of the potencies of GABA-receptor agonists and antagonists using the rat hippocampal slice preparation. Br J Pharmacol 87:677-684.

Khawaled R, Bruening-Wright A, Adelman JP, Maylie J (1999) Bicuculline block of small-conductance calcium-activated potassium channels. Pflugers Arch 438:314-321.

Kluck RM, Bossy-Wetzel E, Green DR, Newmeyer DD (1997) The release of cytochrome $\mathrm{c}$ from mitochondria: a primary site for Bcl-2 regulation of apoptosis. Science 275:1132-1136.

Korn SJ, Dingledine R (1986) Inhibition of GABA uptake in the rat hippocampal slice. Brain Res 368:247-255.

Kreisman NR, LaManna JC, Liao S-C, Yeh ER, Alcala JR (1995) Light transmittance as an index of cell volume in hippocampal slices: optical differences of interfaced and submerged positions. Brain Res 693:179-186.

Levy LM, Warr O, Attwell D (1998) Stoichiometry of the glial glutamate transporter GLT-1 expressed inducibly in a CHO cell line selected for low endogenous $\mathrm{Na}^{+}$-dependent glutamate uptake. J Neurosci 18:9620-9628.

Lipton P (1999) Ischemic cell death in brain neurons. Physiol Rev 79:1431-1568.

Lukasiuk K, Pitkanen A (2000) $\mathrm{GABA}_{\mathrm{A}}$-mediated toxicity of hippocampal neurons in vitro. J Neurochem 74:2445-2454.

Madl JE, Burgesser K (1993) Adenosine triphosphate depletion reverses sodium-dependent, neuronal uptake of glutamate in rat hippocampal slices. J Neurosci 13:4429-4444.

Madl JE, Royer SM (2000) Glutamate dependence of GABA levels in neurons of hypoxic and hypoglycemic rat hippocampal slices. Neuroscience 96:657-664.

Manabe T, Yoshimori T, Henomatsu N, Tashiro Y (1993) Inhibitors of vacuolar-type $\mathrm{H}^{+}$-ATPase suppress proliferation of cultured cells. J Cell Physiol 157:445-452.

Nowicky AV, Duchen MR (1998) Changes in $\left[\mathrm{Ca}^{2+}\right]_{\mathrm{i}}$ and membrane currents during impaired mitochondrial metabolism in dissociated rat hippocampal neurons. J Physiol (Lond) 507:131-145.

Olney JW, Price MT, Samson L, Labruyere J (1986) The role of specific ions in glutamate neurotoxicity. Neurosci Lett 65:65-71.

Otsubo K, Katayama Y, Terashi A (1993) Protective effects of glycerol and mannitol on delayed neuronal death in the gerbil hippocampus. Nippon Ika Daigaku Zasshi 60:231-240.

Overstreet LS, Jones MV, Westbrook GL (2000) Slow desensitization regulates the availability of synaptic $\mathrm{GABA}_{\mathrm{A}}$ receptors. J Neurosci 20:7914-7921.

Phillis JW (1995) CI-966, a GABA uptake inhibitor, antagonizes ischemiainduced neuronal degeneration in the gerbil. Gen Pharmacol 26:1061-1064.

Phillis JW, Smith-Barbour M, Perkins LM, O’Regan MH (1994) Characterization of glutamate, aspartate, and GABA release from ischemic rat cerebral cortex. Brain Res Bull 34:457-466.

Rader RK, Lanthorn TH (1989) Experimental ischemia induces a persistent depolarization blocked by decreased calcium and NMDA antagonists. Neurosci Lett 99:125-130.

Reiner PB, Laycock AG, Doll CJ (1990) A pharmacological model of ischemia in the hippocampal slice. Neurosci Lett 119:175-178. 
Ribak CE, Tong WMY, Brecha NC (1996) GABA plasma membrane transporters, GAT-1 and GAT-3, display different distributions in the rat hippocampus. J Comp Neurol 367:595-606.

Richerson GB, Wu Y (2003) Dynamic equilibrium of neurotransmitter transporters: not just for reuptake anymore. J Neurophysiol 90:1363-1374.

Roettger V, Lipton P (1996) Mechanism of glutamate release from rat hippocampal slices during in vitro ischemia. Neuroscience 75:677-685.

Ropert N, Miles R, Korn H (1990) Characteristics of miniature inhibitory postsynaptic currents in CA1 pyramidal neurones of rat hippocampus. J Physiol (Lond) 428:707-722.

Rossi D, Oshima T, Attwell D (2000) Glutamate release in severe brain ischaemia is mainly by reversed uptake. Nature 403:316-321.

Rossi DJ, Hamann M, Attwell D (2003) Multiple modes of GABAergic inhibition of rat cerebellar granule cells. J Physiol (Lond) 548:97-110.

Rothman SM (1985) The neurotoxicity of excitatory amino acids is produced by passive chloride influx. J Neurosci 5:1483-1489.

Saransaari P, Oja SS (1997) Enhanced GABA release in cell-damaging conditions in the adult and developing mouse hippocampus. Int J Dev Neurosci 15:163-174.

Staley KJ, Soldo BL, Proctor WR (1995) Ionic mechanisms of neuronal excitation by inhibitory $\mathrm{GABA}_{\mathrm{A}}$ receptors. Science 269:977-981.

Stelzer A, Shi H (1994) Impairmant of $\mathrm{GABA}_{\mathrm{A}}$ receptor function by $\mathrm{N}$-methyl-D-aspartate-mediated calcium influx in isolated CA1 pyramidal cells. Neuroscience 62:813-828.

Szatkowski M, Attwell D (1994) Triggering and execution of neuronal death in brain ischaemia: two phases of glutamate release by different mechanisms. Trends Neurosci 17:359-365.

Takahashi T, Hori T, Kajikawa Y, Tsujimoto T (2000) The role of GTPbinding protein activity in fast central synaptic transmission. Science 289:460-463.

Tanaka E, Yamamoto S, Kudo Y, Mihara S, Higashi H (1997) Mechanisms underlying the rapid depolarization produced by deprivation of oxygen and glucose in rat hippocampal CA1 neurons in vitro. J Neurophysiol 78:891-902.
Torp R, Arvin B, Le Peillet E, Chapman AG, Ottersen OP, Meldrum BS (1993) Effect of ischaemia and reperfusion on the extra- and intracellular distribution of glutamate, glutamine, aspartate and GABA in the rat hippocampus, with a note on the effect of the sodium channel blocker BW1003C87. Exp Brain Res 96:365-376.

Wahl F, Obrenovitch TP, Hardy AM, Plotkine M, Boulu R, Symon L (1994) Extracellular glutamate during focal cerebral ischaemia in rats: time course and calcium-dependency. J Neurochem 63:1003-1011.

Wu Y, Wang W, Richerson GB (2001) GABA transaminase inhibition induces spontaneous and enhances depolarization-evoked GABA efflux via reversal of the GABA transporter. J Neurosci 21:2630-2639.

Yamamoto S, Tanaka E, Higashi H (1997) Mediation by intracellular calcium-dependent signals of hypoxic hyperpolarization in rat hippocampal CA1 neurons in vitro. J Neurophysiol 77:386-392.

Yan XX, Cariaga WA, Ribak CE (1997) Immunoreactivity for GABA plasma membrane transporter, GAT-1, in the developing rat cerebral cortex: transient presence in the somata of neocortical and hippocampal neurons. Dev Brain Res 99:1-19.

Yang J, Liu X, Bhalla K, Kim CN, Ibrado AM, Cai J, Peng TI, Jones DP, Wang X (1997) Prevention of apoptosis by Bcl-2: release of cytochrome c from mitochondria blocked. Science 275:1129-1132.

Yeung JY, Canning KJ, Zhu G, Pennefather P, MacDonald JF, Orser BA (2003) Tonically activated GABAA receptors in hippocampal neurons are high-affinity, low-conductance sensors for extracellular GABA. Mol Pharmacol 63:2-8.

Zeevalk GD, Nicklas WJ (1996) Attenuation of excitotoxic cell swelling and GABA release by the GABA transport inhibitor SKF 89976A. Mol Chem Neuropathol 29:27-36.

Zerangue N, Kavanaugh MP (1996) Flux coupling in a neuronal glutamate transporter. Nature 383:634-637.

Zhou Q, Petersen CCH, Nicoll RA (2000) Effects of reduced vesicular filling on synaptic transmission in rat hippocampal neurones. J Physiol (Lond) 525:195-206. 